\title{
KEMITRAAN PENGELOLAAN PARIWISATA DALAM MENINGKATKAN PENDAPATAN ASLI DAERAH KABUPATEN TASIKMALAYA TAHUN 2017 (Studi Kasus Objek Wisata Gunung Galunggung Kabupaten Tasikmalaya)
}

\author{
Gustian Riadi Saputra \\ Mahasiswa Prodi Ilmu Pemerintahan \\ Universitas Muhammadiyah Yogyakarta \\ Gustianriadisaputra1@gmail.com \\ Muchamad Zaenuri \\ Dosen Prodi Ilmu Pemerintahan \\ Universitas Muhammadiyah Yogyakarta \\ Muchamadzaenuri@umy.ac.id \\ Eko Priyo Purnomo \\ Dosen Prodi Ilmu Pemerintahan \\ Universitas Muhammadiyah Yogyakarta \\ eko@umy.ac.id \\ Helen Dian Fridayani \\ Dosen Prodi Ilmu Pemerintahan \\ Universitas Muhammadiyah Yogyakarta \\ Helendianf9@gmail.com
}

\begin{abstract}
Partnership is a breakthrough implemented by the Local Government and Perhutani Company. Considering that Gunung Galunggung tourism in Tasikmalaya Regency is the purpose of the Regency Government to make world tourism, especially Mount Galungung has the highest average number of visitors every year among other tourism objects in Tasikmalaya Regency. This study aims to describe the partnership of Tourism Management and the impact of Partnerships in Managing Mount Galungung Tourism Objects between the Tasikmalaya Regency Tourism, Youth and Sports Department, Perhutani Company and the community. Based on the type of research, this study uses qualitative research conducted in descriptive research in case study research. The data collection technique used is using interview techniques, observation and documentation. Mount Galunggung carried out by the Regency Government, Perhutani Company with the community, which is with the Partnership method where the association activities at Mount Galunggung are the result of an agreement letter through Momentum of Understanding and a work agreement with the community. The partnership runs on the basis of agreed work contracts which are analyzed through 3 principles, namely (1) The equality principle shows that the compilation of each party has equal status, there is already an organizational structure seen in the compilation of relations that have been built by each party. This
\end{abstract}


mutual benefit principle can be seen from the existence of labor savings, can help reduce poverty and savings in the village and help the community to improve welfare. As for the sharing of the results of the ownership of Regency and Perhutani company is $70 \%$ and society (Kompepar and Koparga) 30\% (3) Openness Principle (transparency) This has been agreed transparently on each party that is open in tourism management related to the interests of Mitra Mitra (kompepar) related to parking agreements.

Keywords: Tourism Management, Partnership, Local Revenue.

\begin{abstract}
ABSTRAK
Kemitraan merupakan terobosan yang dilaksanakan oleh Pemerintah Kabupaten dan PT.Perhutani. mengingat wisata Gunung Galunggung Kabupaten Tasikmalaya adalah tujuan Pemerintah Kabupaten untuk menjadikan wisata dunia, terlebih Gunung Galungung mempunyai rata-rata jumlah pengunjung pertahun paling tinggi di antara obyek wisata lain yang ada di Kabupaten Tasikmalaya. Penelitian ini bertujuan untuk mendeskripsikan kemitraan Pengelolaan pariwisata dan Dampak dari Kemitraan Dalam Pengelolaan Objek Wisata Gunung Galungung antara Dinas Pariwisata, Pemuda dan Olahraga Kabupaten Tasikmalaya, PT.Perhutani dengan masyarakat. Berdasarkan jenis penelitianya, maka penelitian ini menggunakan pendekatan kualitatif yang dilakukan dalam penelitian deskriptif pada penelitian studi kasus. Teknik pengambilan data yang digunakan yaitu menggunakan teknik wawancara, observasi serta dokumentasi. Hasil penelitian menunjukan bahwa proses pengelolaan pariwisata di Obyek Wisata Gunung Galunggung yang di lakukan oleh Pemerintah Kabupaten, PT.Perhutani dengan Masyarakat yaitu dengan metode Kemitraan dimana kegiatan pengelolaan pariwisata di Gunung Galunggung yaitu adanya Surat perjanjian melalu M.O.U dan Kontrak Kerja dengan pihak Masyarakat. Kemitraan berjalan bedasarkan kontrak kerja yang sudah di sepakati yang di analisis melaui 3 prinsip yaitu (1) Prinsip Kesetaraan terlihat ketika masing-masing pihak sudah sejajar kedudukannya, sudah memiliki struktur organisasi terlihat ketika alur koordinasi yang sudah dibangun oleh masing-masing pihak (2) Prinsip Azas Manfaat Bersama (mutual benefit) prinsip ini terlihat dengan adanya penyerapan tenaga kerja, dapat membantu mengurangi angka kemiskinan dan pengangguran di desa serta membantu masyarakat guna meningkatkan kesejahteraan.Adapun pembagian hasil pengelolaan pihak Pemerintah Kabupaten dan PT.Perhutani memiliki kesepakatan bagi hasil yaitu $70 \%$ dan Mayarakat (Kompepar dan Koparga) sebesar 30\% (3) Prinsip Keterbukaan (tranparansi) hal ini sudah dikatakan transparan dimana masing-masing pihak terbuka dalam pengelolaan pariwisata tetapi adanya keluhan dari Pihak Mitra(kompepar) terkait pengelolaan lahan parkir.
\end{abstract}

Kata Kunci : Pengelolaan pariwisata, Kemitraan, Pendapatan Asli Daerah 


\section{Pendahuluan}

Pariwisata adalah salah satu hal yang sangat penting bagi negara. Dengan adanya pariwisata, suatu negara atau lebih khusus lagi Pemerintah Daerah tempat obyek wisata itu memberikan pendapatan secara khusus atau pemasukan bagi pendapatan daerah (Fandi, 2012) Sektor pariwisata dinyatakan sebagai salah satu pengaruh kuat dalam perkembangan wilayah di daerah sekitar obyek wisata. Partiwisata Indonesia diharapkan mampu untuk berperan sebagai penentu dan katalisator mengembangkan pembangunan sektor lainnya secara bertahanp yoeti (dalam Farrah, 2017) Oleh karena itu sektor pariwisata Indonesia menjadi sorotan. Industri pariwisata di Indonesia harus mendapat perhatian secara khusus dari pemerintah baik pusat maupun daerah dalam mengembangkan pariwisatanya.

Pengelolaan kegiatan pariwisata tentu sangat diperlukan dalam upaya menahan wisatawan untuk tinggal lebih lama di daerah tujuan wisata dan bagaimana wisatawan membelanjakan uang sebanyak- banyaknya selama melakukan wisata. Makin lama wisatawan berada di suatu tempat wisata akan meningkatkan pengeluaran mereka, sehingga akan membangkitkan perusahan jasa transportasi, hiburan, akomodasi, dan jasa lainnya Wardana (2017). Oleh karena itu pengelolaan dan memanfaatkan potensi pariwisata yang dimiliki daerah juga dikelola oleh masing-masing daerah. Begitu juga dengan kota dan kabupaten tasikmalaya yang memiliki banyak potensi dan sumber daya alam yang dapat dikembangkan sebagai daya Tarik wisata.

Kabupaten Tasikmalaya merupakan salah satu wilayah yang sangat berdekatan dengan Kota Tasikmalaya. Kabupaten Tasikmalaya memiliki banyak sekali potensi wisata, namun sayangnya beberapa destinasi wisata yang ada di wilayah ini belum dapat dikembangkan dan dikelola secara optimal. Kota dan kabupaten tasikmalaya mempunyai kurang lebih 40 destinasi wisata. Banyaknya objek wisata yang ada pengelolaan terhambat karena kurangnya pemerhati pemerintah secara khusus untuk mengelola objek wisata tersebut.

Pengelolaan objek wisata gunung galunggung yang dilakukan secara kemitraan (antara pemerintah kabupaten maupun PT.Perhutani dengan masyarakat lokal) dapat memanfaatkannya sebagai pendongkrak dalam 
pembangunan daerah. Kemitraan ini menjadi penting, mengingat selama ini pembangunan yang dilakukan hanya menjadikan pemerintah kabupaten sebagai objek pembangunan saja (kabar priangan.ac.id.2016).

Obyek wisata gunung galunggung ini di tunjang wisata edukasi (mempelajari letusan dan sejarah Gunung Galunggung) pengelolaan pariwisata yang terjadi di Obyek Wisata Gunung Galunggung Kabupaten Tasikmalaya dimana dalam pengelolaan pariwisatanya melakukan kerjasama atau kemitraan antara Dinas Pariwisata, pemuda dan Olahraga serta Perhutani dengan masyarakat yang mempunyai tujuan yaitu meningkatkan Pendapatan Asli Daerah sebagaimana pada hasl wawancara dengan bapak toni dari dinas pariwisata bahwa kemitraan ini sudah sepakat dengan pihak masyarakat dalam hal ini adalah Kompepar (kelompok penggerak pariwisata) sudah terjalin sejak tahun 2003 melalui penggabungan Retribusi pada bulan Maret yang telah sepakat melalui SK (Surat Keputusan) dalam bermitra untuk pengelolaan pariwisata dan pengelolaan tersebut dibagi 2 yaitu oleh DISPARPORA dan PT Perhutani Jabar banten yang melibatkan masyarakat untuk berpartisipasi dalam pengelolaan tersebut yaitu Koparga (koperasi pariwisata Galunggung) dimulai kurang lebih sejak tahun 2000 pada saat itu di legalkan melalui atas dasar Keputusan Menteri Negara koperasi \& Pengusaha Kecil Menengah RI No.56/BH/KDK.10.15/VIII/2000.

Pada halaman Republika.co.id (2018) disebutkan bahwa Dinas Pariwisata, Pemuda dan Olahraga Kabupaten Tasikmalaya sedang fokus untuk membenahi 3 destinasi wisata yang mereka miliki untuk mendunia, ke 3 destinasi wisata tersebut yaitu Kampung Naga yang menyuguhkan hal-hal yang berkaitan dengan kearifan lokal, Wisata Gunung Galunggung yang menyuguhkan wisata alam dan juga bisa dijadikan sebagai wisata edukasi (mempelajari letusan dan sejarah Gunung Galunggung), dan kemudian yang terakhir adalah objek wisata di pesisir selatan Kabupaten Tasikmalaya (salah satunya wisata Pantai Karangtawulan). Gunung galunggung adalah salah satu objek wisata yang terletak di jawa barat, desa linggajati, kabupaten tasikmalaya. Jarak dari pusat kota tasikmalaya sekitar $17 \mathrm{~km}$. Terdapat beberapa daya tarik tersendiri gunung galunggung menawarkan wanawisata dengan areal seluas kurang lebih 120 hektar di bawah pengelolaan Perum Perhutani dan Dinas Pariwisata dan Budaya (Mukhsi, 2015). 
$302 \mid$ Gustian Riadi Saputra,dkk. Kemitraan Pengelolaan Pariwisata...

Tabel 1 : Data Kunjungan Arus Wisatawan Yang Berkunjung Ke Gunung Galunggung Kabupaten Tasikmalaya 2015-2017

\begin{tabular}{|c|c|c|c|c|}
\hline \multirow{2}{*}{ No } & Objek wisata & \multicolumn{3}{|c|}{ Tahun } \\
\cline { 2 - 5 } & Wana wisata & $\mathbf{2 0 1 5}$ & $\mathbf{2 0 1 6}$ & $\mathbf{2 0 1 7}$ \\
\hline $\mathbf{1}$ & Gunung Galunggung & 241,813 & 235,293 & 373,159 \\
\hline
\end{tabular}

(2018)

Data diatas menunjukan terjadi Penurunan kunjungan wisatawan ke Wana Wisata Gunung Galunggung dari tahun 2015 sampai 2016 sebanyak 6,52 dengan penurunan pertumbuhan kunjungan menurun sebesar 0,42 persen, Namun terjadi kenaikan kunjungan wisatawan dari tahun 2016 menuju tahun 2017 sebanyak 137,866 dengan peningkatan pertumbuhan kunjungan sebesar 37.02 persen. Peningkatan tersebut disebabkan dengan adanya system perubahan tatakelola dan tercapainya target dari hasil pengelolaan pariwisata di Gunung Galunggung. Perlunya optimalisasi dalam pengelolaan tersebut maka dari itu juga harus dilakukan kerjasama atau kemitraan melalui pendekatan organisasi pariwisata yang ada yang terdiri dari pemerintah, masyarakat dan pihak-pihak terkait yang mendukung kelanjutan pembangunan di daerah itu Fandi, (2012) Akan tetapi pengelolaan tersebut menjadi kontoversi besar terhadap pemerintah kabupaten tasikmalaya karena masih menjadi tugas pemerintah kabupaten untuk pembenahan retribusi agar tidak adanya pungutan liar, dan pemerintah kabupaten tasikmalaya berupaya untuk mengoptimalkan PAD dari sektor pariwisata dengan menaikan tarif tiket masuk obyek wisata (validnews, 2018)

Tabel 2 : Data Pendapatan Asli Daerah Obyek Wisata Gunung Galunggung Kabupaten Tasikmalaya Tahun 2015-2017

\begin{tabular}{|c|c|c|c|c|}
\hline No & Wana Wisata & $\begin{array}{l}2015 \\
(\mathrm{Rp})\end{array}$ & $\begin{array}{l}2016 \\
(\mathrm{Rp})\end{array}$ & $\begin{array}{l}2017 \\
(\mathrm{Rp})\end{array}$ \\
\hline 1 & $\begin{array}{c}\text { Kawasan Wisata } \\
\text { Galunggung }\end{array}$ & 642.142 .000 & 557.501 .000 & 616.754 .000 \\
\hline 2 & $\begin{array}{c}\text { Bak Rendam Air Panas } \\
\text { Galunggung }\end{array}$ & 58.783 .000 & 61.254 .000 & 73.763 .000 \\
\hline
\end{tabular}

Sumber : Dinas Pariwisata, Pemuda dan Olahraga Kabupaten Tasikmalaya (2018) 
Dapat dilihat data diatas bahwa adanya peningkatan jumlah pendapatan wisata pemandian air panas yang signifikan pada tahun 2015 hingga 2017. Namun juga terjadi penurunan pendapatan yang dialami oleh kawasan wisata gunung galunggung pada tahun 2015 hingga 2016 sebesar 84.646.000 meskipun pada tahun 2016 hingga tahun 2017 mengalami kenaikan tetapi jumlah dari tahun 2015 hingga 2017 sangat tipis angka kenaikan pendapatan. Yang merupakan dampak dari berkurangnya jumlah pengunjung seiring dengan di naikkan nya tarif atau reribusi masuk ke wana wisata gunung galunggung pada tahun 2017 .

Beragam fakta tersebut mengindikasikan bahwa kerjasama yang di terapkan belum mendukung penuh dalam pengembangan pengelolaan pariwiata di gunung galunggung. Pengelolaan objek wisata gunung galunggung yang dilakukan secara kemitraan (antara pemerintah kabupaten maupun PT.Perhutani dengan masyarakat lokal) dapat memanfaatkannya sebagai pendongkrak dalam pembangunan daerah. Kemitraan ini menjadi penting, mengingat selama ini pembangunan yang dilakukan hanya menjadikan pemerintah kabupaten sebagai objek pembangunan saja (kabar priangan.ac.id.2016). Sehingga dapat di lihat bahwa untuk menanggulangi permasalahan pengelolaan ini seharusnya di atur dalam perjanjian pengelolaan kolaborasi antara Dinas Pariwisata, Pemuda dan Olahraga Kabupaten Tasikmalaya, Perhutani dengan Masyarakat yang di kelompokan menjadi jaringan masyarakat penggerak pariwisata atau KOMPEPAR serta KOPARGA (Koperasi Pariwisata Galunggung). Harapannya dapat menajaga dan melestarikan dengan adanya kemitraan dalam pengelolaan obyek wisata diharapkan masyarakat dapat berperan aktif dalam pengelolaan pembangunan wisata gunung galunggung. Sehingga pembangunan dapat dirasakan oleh masyarakat lokal yang berada di kawasan obyek wisata dan bisa meningkatkan Pendapatan Asli Daerah (PAD).

\section{Tinjauan Pustaka}

\section{a. Kemitraan}

Kemitraan Secara Harafiah, menurut Kamus Besar Bahasa Indonesia (KBBI), Kemitraan berasal dari kata Mitra yang berarti teman, kawan kerja, pasangan kerja, dan atau rekan. Jika diberi imbuhan "ke-an", maka menjadi 
kata Kemitraan yang artinya perihal hubungan atau jalinan kerjasama sebagai mitra.

Putra (2013) menyebutkan bahwa Kemitraan adalah suatu konsep kerjasama yang memiliki kriteria seperti dilakukan lebih dari satu pihak, mempunyai kebutuhan masing-masing, namun sepakat mencapai visi dan tujuan untuk meningkatkan kapasitas. Menurut Sulistyani (dalam Putra, 2013) , kemitraan dalam perspekstif etimologis diadaptasi dari kata Partnership dan berasal dari akar kata partner, yang berarti "pasangan, jodoh, sekutu, atau komponen". Sedangkan partnership diterjemahkan menjadi persekutuan atau perkongsian. Dengan demikian, kemitraan dapat dimaknai sebagai satu bentuk persekutuan antara dua belah pihak atau lebih yang membentuk suatu ikatan kerjasama atas dasar kesepakatan dan rasa saling membutuhkan dalam rangka meningkatkan kapabilitas di suatu bidang usaha tertentu atau tujuan tertentu, sehingga dapat memperoleh hasil yang lebih baik.

Notoatmodjo (2003) menyatakan bahwa kemitraan dapat terbentuk apabila memenuhi persyaratan sebagai berikut:

a. Terdapat dua pihak atau lebih, merupakan pemerintah, swasta dan masyarakat.

b. Memiliki kesamaan visi dalam mencapai tujuan bersama dalam pengelolaan Tirta Wisata.

c. Ada kesepakatan antara pemerintah dan swasta dalam pengelolaan Tirta Wisata yang dapat memberikan efek positif terhadap perekonomian masyarakat sekitar.

d. Saling membutuhkan antara pihak pemerintah, swasta dan masyarakat memiliki peran masing-masing dalam pengelolaan Tirta Wisata.

Bentuk-bentuk/tipe kemitraan menurut Pusat Promosi Kesehatan Departemen Kesehatan RI yaitu terdiri dari aliansi, koalisi, jejaring, konsorsium, kooperasi dan sponsorship. Bentuk-bentuk kemitraan tersebut dapat tertuang dalam :
a. SK Bersama
b. MOU
C. Pokja 
d. Forum Komunikasi

e. Kontrak Kerja/perjanjian kerja

Ada macam-macam tujuan kemitraan yang dilakukan oleh dua orang atau lebih menurut Hafsah (dalam Nurfadilah, 2017) kondisi sosial yang ideal, tujuan yang ingin dicapai dalam pelaksanaan kemitraan adalah

1. Meningkatkan pendapatan

2. Meningkatkan perolehan nilai tambah

3. Meningkatkan efisiensi

4. Menciptakan pemeratan

5. Memperluas kesempatan kerja

6. Pemberdayaan masyarakat usaha kecil

7. Meningkatkan pertumbuhan ekonomi pedesaan, wilayah, dan nasional.

8. Menghindari kecemburuan sosial yang akan menimbulkan gejolak sosial.

Menurut kuswidanti (dalam Petang et al., 2010)Terdapat 3 prinsip kunci yang perlu di pahami dalam membangun suatu kemitraan oleh masing-masing anggota yaitu :

1. Prinsip Kesetaraan

Individu, organisasi atau institusi yang telah bersedia menjalin kemitraan harus merasa sama atau sejajar kedudukannya dengan yang lain dalam mencapai tujuan yang disepakati

2. Primsip keterbukaan

Keterbukaan terhadap kekurangan atau kelemahan masingmasing anggota serta berbagai sumber daya yang dimiliki. Semua itu harus diketahui oleh anggota lain. Keterbukaan ada sejak awal dijalinnya kemitraan sampai berakhirnya kegiatan. Dengan saling keterbukaan ini akan menimbulkan saling melengkapi dan saling membantu diantara golongna (mitra).

3. Prinsip azas manfaat bersama (mutual benefit) 
Individu, organisasi atau institusi yang telah menjalin kemitraan memperoleh manfaat dari kemitraan yang terjalin sesuai dengan kontribusi.

Dari uraian di atas maka dapat disimpulkan bahwa kemitraan merupakan jalinan usaha yang merupakan stratergi dalam pembangunan untuk tercapainya tujuan yang dilakukan oleh dua pihak atau lebih dengan prinsip membutuhkan, saling memperkuat dan saling menguntungkan yang disertai adanya satu pembinan dan pengembangan.

Tujuan terjadinya suatu kemitraan adalah untuk mencapai hasil yang lebih baik, dengan saling memberikan manfaat antar pihak yang bermitra. Dengan demikian kemitran hendaknya memberikan keuntungan antara pihakpihak yang bermitra, dan bukan sebaliknya ada sutu pihak yang dirugikan atau merugikan. Untuk terjadinya suatu kemitraan yang kuat dan saling menguntungkan serta memperbesar manfaat memmerlukan komitmen yang seimbang antara satu dengan lainnya Sulistiyani (dalam Nurfadilah, 2017)

\section{b. Pengelolaan Pariwisata}

Pengelolaan dalam kamus besar bahasa indonesia di definisikan sebagai berikut :
a. Proses, cara, perbuatan mengelola
b. Proses melakukan perbuatan tertentu denga menggerakan tenaga orang lain,
c. Proses yang membantu merumuskan kebijaksanaan dan tujuan organisasi
d. Proses yang memberikan pengawasan pada semua hal yang terlibat dalam pelaksanaan kebijaksanaan dan pencapaian tujuan.

Menurut terry (dalam Kanuna, 2014) pengelolaan (management) merupakan sebuah proses yang khas, yang terdiri dari tindakan-tindakan: perencanaan, pengorganisasian, dan pengawasan yang dilakukan untuk menentukan serta mencapai sasaran-sasaran yang telah ditetapkan melalui pemanfaatan sumber daya manusia dan sumber-sumber lainnya. Sejalan dengan Terry dkk, (dalam Kanuna, 2014) juga mendefinisikan manajemen sebagai seni perencanaan, pengorganisasian, pengarahan, pengkoordinasian, 
dan pengontrolan atas human and national resources (terutama human resources) untuk mencapai tujuan yang telah ditentukan lebih dahulu.

Kanuna (2014) Pengelolaan merupakan suatu proses kegiatan yang meliputi perencanaan, pengorganisasian, pelaksanaan dan pengawasan.

a. Perencanaan (Planning), adalah suatu pemeliharaan yang berhubungan dengan waktu yang akan datang dalam menggambarkan dan merumuskan kegiatan-kegiatan yang diusulkan demi mencapai hasil yang dikehendaki.

b. Pengorganisasian (Organizing), adalah penentuan, pengelompokan, dan pengaturan berbagai kegiatan yang dianggap perlu untuk mencapai tujuan.

c. Pelaksanaan (Actuating), adalah usaha agar setiap anggota kelompok mengusahakan pencapaian tujuan dengan berpedoman pada perencanaan dan usaha pengorganisasian.

d. Pengawasan (Controlling), adalah proses penentuan apa yang seharusnya diselesaikan yaitu penilaian pelaksanaan, bila perlu melakukan tindakan korektif agar pelaksanaannya tetap sesuai dengan rencana.

Adapun pengertian mengenai pariwisata secara etimologis Pariwisata berasal dari Bahasa Sansekerta yang terdiri dari dua kata yaitu "Pari" dan Wisata. Pari yang berarti ber ulang-ulang, berkali-kali atau berputar-putar, sedangkan wisata berarti perjalanan atau bepergian jadi dapat disimpulkan bahwa Pariwisata yaitu perjalanan yang dilakukan secara berputar-putar, berulang-ulang atau berkali-kali. Saputro (2016) mengemukakan bahwa Pariwisata merupakan perpindahan sementara yang dilakauakan manusia dengan tujuan keluar dari pekerjaan/rutinitas sehari-hari, keluar dari kediamannya. Secara demikian pariwisata berarti dari kata pariwisata suatu perjalanan yang dilaakukan secara berkali-kali atau berputar-putar daru suatu tempat ke tempat lain.

Menurut definisi pengertian dari pariwisata yang di katakan oleh Spillane (dalam Nurfadilah, 2017) Menyebutkan bahwa pariwisata merupakan perjalanan dari suatu tempat ke tempat lain, bersifat sementara, dilakukan perorang maupun kelompok, sebagai usaha mencari keseimbangan atau 
keserasian dan kebahagiaan dengan lingkungan hidup dalam dimensi sosial, budaya, alam, dan ilmu.

Menurut Undang-Undang Nomor 10 tahun 2009 pasal 1, kepariwisataan adalah keseluruhan kegiatan yang terkait dengan pariwisata dan bersifat multidimensi serta multidisiplin yang muncul sebagai wujud kebutuhan setiap orang dan negara serta interaksi antara wisatawan dan masyarakat setempat, sesama wisatawan, pemerintah, pemerintah daerah, dan pengusaha. Sedangkan Pariwisata menurut Peraturan Daerah Kota Tasikmalaya No.8 Tahun 2014 tentang Penyelenggaraan Kepariwisataan bahwa pariwisata adalah berbagai macam kegiatan wisata dan di dukung berbagai fasilitas serta layanan yang disediakan oelh masyarakat, pengusaha, Pemerintah dan Pemerintah Daerah.

Pengertian yang lain Suwantoro (dalam Beatrix, 2017) menyebutkan bahwa pariwisata adalah suatu proses kepergian sementara dari seorang atau lebih menuju tempat lain keluar tempat tinggalnya. Dorongan kepergian adalah karena berbagai kepentingan, baik karena kepentingan ekonomi, sosial, kebudayaan, politik, agama, kesehatan maupun kepentingan lain seperti karena sekedar ingin tahu, menambah pengalaman ataupun untuk belajar. Istilah pariwisata berhubungan erat dengan perjalanan wisata yaitu sebagai suatu perubahan tempat tinggal sementara seseorang diluar tempat tinggalnya karena suatu alasan dan bukan untuk kegitan menghasilkan upah.

Jenis-jenis wisata ini muncul dikarenakan di setiap daerah maupun suatu negara umumnya dapat menyajikan berbagai atraksi wisata agar dapat menarik perhatian pengunjung wisatawan untuk berkunjung ke daerah tersebut. Dari hal tersebut maka terdapat berbagai jenis pariwisata menurut Marpaung (dalam Abdul, 2015) yaitu :

1. Wisata untuk menikmati perjalanan :

Pariwisata ini dilakukan oleh orang-orang yang meninggalkan tempat tinggalnya untuk berlibur, untuk mendapatkan ketenangan di luar kota dan sebaliknya.

2. Wisata untuk rekreasi :

Jenis wisata ini dilakukan oleh orang yang menghendaki pemanfaatan hari libur untuk beristirahat, melepaskan segala keletihan dan kelelahan, dengan mengunjungi tempat yang 
dianggap menjamin tujuan rekreasi mereka, seperti tepi pantai, pegunungan, dan tujuan untuk menemukan kenikmatan mereka.

3. Wisata untuk Kebudayaan:

Jenis wisata ini ditandai dengan adanya rangkaian motivasi seperti keinginan untuk belajar di pusat riset, mempelajari adat istiadat, dan mengunjungi monumen bersejarah.

Pengelolaan Pariwisata merupakan bagian penting dalam kegiatan pariwisata, tanpa pengelolaan pariwisata tentu tidak akan terciptanya sapta pesona yang akan menarik wisatawan untuk datang berkunjung. Pengelolaan pariwisata haruslah mengacu pada prinsip- prinsip pengelolaan yang menekankan nilai-nilai kelestarian lingkungan alam, komunitas, dan nilai sosial yang memungkinkan wisatawan menikmati kegiatan wisatanya serta bermanfaat bagi kesejahteraan komunitas lokal.

Cox (dalam Amim, 2017), pengelolaan pariwisata harus memperhatikan prinsip- prinsip berikut:

1. Pembangunan dan pengembangan pariwisata haruslah didasarkan pada kaerifan lokal dan special local sense yang merefleksikan keunikan peninggalan budaya dan keunikan lingkungan.

2. Preservasi, proteksi, dan peningkatan kualitas sumber daya yang menjadi basis pengembangan kawasan pariwisata.

3. Pengembangan atraksi wisata tambahan yang mengakar pada khasanah budaya lokal.

4. Pelayanan kepada wisatawan yang berbasis keunikan budaya dan lingkungan lokal.

5. Memberikan dukungan dan legitimasi pada pembangunan dan pengembangan pariwisata jika terbukti memberikan manfaaat positif, tetapi sebaliknya mengendalikan dan/atau menghentikan aktivitas pariwisata tersebut jika melampaui ambang batas (carrying capacity) lingkungan alam atau akseptabilitas sosial walaupun di sisi lain mampu meningkatkan pendapatan masyarakat.

Untuk menyinergikan pengelolaan pariwisata yang memenuhi prinsip- 
310 | Gustian Riadi Saputra,dkk. Kemitraan Pengelolaan Pariwisata...

prinsip pengelolaan yang diurikan sebelumnya, diperlukan suatu metode pengelolaan yang menjamin keterlibatan semua aspek dan komponen masyarakat. Metode Pengelolaan pariwisata mencangkup beberapa kegiatan berikut WTO, dalam Richardson dan Fluker (dalam Amim, 2017) :

1. Pengolsutasian dengan semua pemangku kepentingan Hal ini dapat dilakukan dengan beragam cara, seperti melalui pertemuan formal dan terstrukutr dengan pelaku industry pariwisata, dewan pariwisata, konsultasi publik dalam subjek tertentu, penjajakan dan survai, konsultasi kebijakan dengan beragam kelompok kepentingan, dan melalui interaksi antara departemen pemerintah terkait dengan berbagai pihak sesuai subjek yang ditentukan.

2. Pengidentifikasian isu

Isu pariwisata akan semakin beragam seiring dengan meningkatnya skala kegiatan yang dilakukan.

3. Penyusunan Kebijakan

Kebijakan yang disusun mungkin akan berdampak langsung maupun tidak langsung dengan pariwisata. Kebijakan ini akan menjadi tuntunan bagi pelaku pariwisata dalam mewujudkan visi dan misi pembangunan pariwisata.

4. Pembentukan dan pendanaan agen dengan tugas khusus Agen ini bertujuan menghasilkan rencana strategi sebagai panduan dalam pemasaran dan pengembangan fisik di daerah tujuan wisata.

5. Penyediaan fasilitas dan operasi

Pemerintah berperan dalam member modal usaha, pemberian subsidi kepada fasilitas dam pelayanan yang vital tetapi tidak mampu membiyayai dirinya sendiri tetapi dalam jangka panjang menjadi penentu keberhasilan pembangunan pariwisata.

6. Penyediaan Kebijakan fiscal, regulasi, dan lingkungan sosial yang kondusif. 
Hal ini terutama diperlukan sebagai prasyarat bagi organisasi / perusahaan untuk mencari keuntungan atau target perusahaan yang telah ditetapkan.

7. Penyelesaian konflik kepentingan dalam Masyarakat

Hal ini merupakan peran yang sulit tetapi akan menjadi salah satu peran yang sangat penting dalam era di mana isu lingkungan dan konservasi sumber daya menjadi isu penting.

Dari prinsip-prinsip yang telah dijabarkan diatas dapat simpulkan bahwa dalam pengelolaan pariwisata sangat diperlukan sinergi atau kerja sama yang baik, konsistensi dan komitmen dari seluruh pemangku kepentingan agar pengelolaan berjalan lancar dan potensi-potensi yang dimiliki dapat di manfaatkan demi kebaikan bersama. Selain itu juga pengelolaan pariwisata sebaiknya memperhatikan kondisi lingkungan seperti menjaga kelestarian lingkungan sekitar, dan mengajak masyarakat untuk berpartisipasi dalam pengelolaannya, karena tujuan awal dari pembangunan pariwisata adalah untuk kesejahteraan masyarakat.

\section{c. Community Governance}

Pemerintah daerah telah memiliki hubungan yang panjang dengan proses komunitas yang kompleks pemerintahan. Munculnya konsep telah dipengaruhi oleh kecenderungan geografis dari istilah 'komunitas' (Delanty 2003) dan 'pemerintahan' yang berarti struktur pemerintahan baru Model pemerintahan yang sedang berkembang mendapatkan popularitas dalam masyarakat dan komunitas sektor adalah Community Governance. Tata kelola komunitas kadang-kadang digunakan untuk merujuk partisipasi masyarakat, keterlibatan dan pengambilan keputusan dalam masalah publik dan terkait dengan istilah-istilah seperti pemerintahan lokal, tata kelola sosial, tata kelola jaringan dan partisipatif pemerintahan (Halsall et al., 2013).

Bourne dkk (dalam Totikidis, 2005) Tata kelola komunitas adalah konsep penting yang perlu klarifikasi lebih lanjut. Sebuah studi tentang tata kelola komunitas pencegahan kejahatan dan keselamatan masyarakat. Dengan contoh di Victoria, baru-baru ini manfaat dari konsep tata kelola komunitas 
yang dilakukan oleh Universitas Victoria dalam kemitraan yaitu Pencegahan Kejahatan Victoria.

Komunitas adalah kelompok yang menganggap dirinya memiliki ikatan yang kuat dan langgeng, terutama ketika kelompok itu berbagi lokasi geografis. Satu ukuran masyarakat adalah partisipasi reguler oleh individu dalam kegiatannya. Yang lainnya adalah kekuatan identifikasi di antara anggota dengan ikatan sosial yang dirasakan kelompok. Yang ketiga adalah ruang fisik spesifik dan lokasi yang umumnya dipahami sebagai wilayah grup. Ruang ini menyediakan set penanda materialnya sendiri komunitas memiliki ikatan emosional yang kuat Gottdiener and Budd (dalam Halsall et al., 2013)

Tujuan dari community governance adalah untuk membangun dan memelihara identitas kolektif di dalamnya otoritas lokal (lihat Gambar 1.3). Banner (dalam Halsall, 2012) telah mendefinisikan tata kelola komunitas sebagai:

Tabel 3 : Tata Kelola Komunitas secara singkat dari Pendekatan Tenaga Kerja Baru.

- "Peran kepemimpinan masyarakat dari dewan dan dunia komunitas yang rumit pemerintahan bukanlah hal baru. Kebijakan pemerintah sekarang membawa mereka ke tengah panggung, menyoroti hubungan kompleks antara organisasi sektor publik, sukarela dan swasta dengan warga negara dan komunitas

- Kepemimpinan masyarakat dapat melibatkan pengembangan visi untuk lokalitas, bekerja di dalamnya

kemitraan untuk mewujudkan visi tersebut dan menjamin layanan berkualitas untuk semua. Baru

pendekatan dan cara kerja baru diperlukan agar dewan menjadi efektif dalam hal ini.

- Proses perencanaan dan kemitraan masyarakat dan cara-cara inovatif untuk melibatkan

warga dan masyarakat akan dibutuhkan karena otoritas lokal menjadi lebih terbuka dan tampak luar.

- Perubahan ini akan membuat tuntutan baru pada anggota dan petugas 
terpilih. Berbeda

hubungan, lebih menekankan pada jaringan dan broker dan keterampilan baru dan

kompetensi akan dibutuhkan.

- Struktur dan proses politik dan mesin petugas dari pemerintah lokal

tumbuh untuk mendukung manajemen dan pengiriman layanan. Kekhawatiran yang lebih luas dari

kepemimpinan komunitas dan tata kelola komunitas akan mengubahnya. "

Keterlibatan komunitas adalah komunikasi timbal balik dan musyawarah yang terjadi antara pemerintah dan warga negara. Ini memungkinkan warga dan pemerintah untuk berpartisipasi bersama dalam perumusan kebijakan dan penyediaan layanan pemerintah, tetapi seringkali dengan final tanggung jawab berbohong dengan pemerintah terpilih OECD (dalam Totikidis, 2005). Idealnya tautan itu tindakan pemerintah dengan aksi komunitas untuk kemajuan komunitas dan tujuan pemerintah. Berbagai pengaturan, struktur, dan proses dapat memediasi interaksi ini.

Dapat disimpulkan bahwa meskipun tata kelola komunitas adalah yang pertama tentang komunitas manajemen dan pengambilan keputusan konsep pemerintahan masyarakat juga berimplikasi pada tujuan yang lebih luas dalam menangani kebutuhan masyarakat dan membangun kapasitas komunitas.

\section{d. Pendapatan Asli Daerah (PAD)}

Menurut Abdul halim (dalam Lestari sri, 2014) Pendapatan Asli Daearah adalah penerimaan yang diperoleh daerah dari sumber-sumber dalam wilayahnya sendiri yang dipungut berdasarkan peraturan daerah sesuai dengan peraturan perundang-undangan yang berlaku. Sektor pendapatan daerah memegang peranan yang sangat penting, karena melalui sektor ini dapat dilihat sejauh mana suatu daerah dapat membiayai kegiatan pemerintah dan pembangunan daerah. Menurut Undang-Undang No. 23 tahun 2014 Tentang Pemerintah Daerah dan Undang-Undang No 33 tahun 2004 tentang Perimbangan Keuangan Antara Pemerintah Pusat Dan Pemerintah Daerah Pendapatan Asli Daerah, selanjutnya disebut PAD adalah pendapatan yang diperoleh Daerah yang dipungut berdasarkan Peraturan Daerah sesuai dengan 
peraturan perundang-undangan. Sedangkan menurut Ahmad yani (dalam Lestari sri, 2014) menjelaskan bahwa Pendapatan Asli Daerah (PAD) adalah pendapatan yang diperoleh daerah yang dipungut berdasarkan peraturan daearah sesuai dengan peraturan perundang-undangan.

Pasal 6 Undang- Undang No 32 Tahun 2004 Tentang Perimbangan Keuangan Antara Pemerintah Pusat Dan Pemerintah Daerah menyebutkan bahwa sumber pendapatan asli daerah terdiri atas :
a. pajak daerah;
b. Retribusi Daerah;
c. Hasil pengelolaan kekayaan Daerah yang dipisahkan; dan
d. Lain-lain PAD yang sah.

Menurut Abdul halim (dalam Lestari sri, 2014) kelompok Pendapatan Asli Daerah (PAD) dipisahkan menjadi empat jenis Pendapatan yaitu :

1) Pajak Daerah

a) Pajak Provinsi, terdiri dari :

Pajak Kendaraan Bermotor dan kendaraan diatas air, Bea Balik Nama Kendaraan Bermotor dan kendaraan di atas air, pajak Bahan Bakar Kendaraan Bermotor, Pajak Pengambilan dan Pemanfaatan Air Bawah Tanah dan Permukaan

b) Pajak Kabupaten/Kota, terdiri dari :

Pajak Hotel, Pajak Restoran, Pajak Hiburan, pajak reklame, Pajak Penerangan Jalan, Pajak Pengambilan dan Pengelolaan Bahan Galian Golongan C, dan pajak parkir.

2) Retribusi Daerah, Terdiri dari :

Retribusi Jasa Umum, Retribusi Jasa Usaha, dan Retribusi Perjanjian tertentu.

3) Hasil Perusahaan milik daerah dan hasil pengelolaan kekayaan daerah yang dipisahkan

4) Lain-lain Pendapatan Asli Daerah (PAD) yang sah yaitu : Hasil penjualan kekayaan daerah yang tidak dipisahkan, hasil pemanfaatan atau pendayagunaan kekayaan daerah yang tidak dipisahkan, jasa giro, pendapatan bunga, tuntutan ganti rugi, keuntungan selisih nilai tukar rupiah terhadap mata uang asing 
dan komisi, potongan, ataupun bentuk lain sebagai akibat dari penjualan dan/atau pengadaan barang dan jasa oleh daerah.

Di samping pajak daerah, sumber pendapatan daerah dapat diperoleh melalui retribusi. Menurut Ibnu syamsi (dalam Yuningsih, 2005) mendefinisikan bahwa retribusi ialah iuran dari masyarakat tertentu (orangorang tertentu) berdasarkan peraturan perundang-undangan yang prestasinya dikembalikan di tunjuk secara langsung, tetapi pelaksanaannya tidak dapat dipaksakan meskipun tidak mutlak.

Sedangkan menurut UU No. 34 Tahun 2000 tentang Perubahan Atas Undang-Undang Republik Indonesia Nomor 18 Tahun 1997 Tentang Pajak Daerah Dan Retribusi Daerah, retribusi dibagi tiga golongan yaitu :

a. Retribusi jasa umum

Jasa yang dimaksud emrupakan kewenangan daerah dalam rangka pelaksanaan desentralisasi

b. Retribusi Jasa Usaha

Jasa yang bersangkutan adalah jasa yang bersifat komersial yang seyogyanya disediakan oleh sector swasta tetapi belum memadai atau terdapatnya harta yang dimiliki atau dikuasasi Daerah yang belum dimanfaatkan secara penuh oleh Pemerintah Daerah

c. Retribusi Perijinan tertentu

Perijinan tersebut termasuk kewenanga pemerintah yang di serahkan kepada Daerah dalam rangka asas desentralisasi

(Pasal 18 ayat (2) UU No. 34 Tahun 2000)

Penetapan jenis-jenis Retribusi Jasa Umum, Jasa Usaha, dan Perijinan tertentu dimaksudkan untuk tercipta ketertiban dalam penerapannya, sehingga dapat memberikan kepastian bagi masyarakat dan di sesuaikan dengan kebutuhan nyata daerah yang bersangkutan. Pemerintah darah juga memiliki hak untuk mengelolan perusahaan sendiri sebagai sumber pendapatannya yang disebut perusahaan daerah (perusada) (Yuningsih., 2005) menyebutkan bahwa prinsip pengelolaan daerah haruslah bersifat professional dan berpegang teguh pada prinsip-prinsip ekonomi secara umum yaitu efisien.

Salah satu tujuan atau maksud dari didirikannya perusahaan daerah adalah didasarkan pada pelayanan dan pemberian jasa kepada masyarakat. 
Namun demikian bukan berarti bahwa perushaan daerah tidak dapat memberikan kontibusi pada Pendapatan Asli Daerah. Perusahan daerah mempunyai dua fungsi yang berjalan secara bersamaan, dimana satu pihak di tunut untuk mnyelenggarakan fungsi-fungsi social, yaitu memberikan pelayanan dan jasa kepada masyarakat dan pihak lain perusahaan daerah menjalankan fungsi ekonomi yaitu keuntungan dan kinerjanya. Keuntungan inilah yang diharapkan yang dapat memberikan sumbangan bagi Pendapatan Asli Daerah.

Usaha daerah sebagai sumber pendapatan daerah harus di setorkan kepada kas daerah diatur dalam peraturan daerah. Dalam pelaksaan otonomi daerah, kabupaten/kota melakukan berbagai upaya terobosan dalam peningkatan perolehan Pendapatan Asli Daerah, sebab faktor dana sangat menentukan lancer tidaknya suatu pemerintah darah. Pelayanan kepada masyarakat akan terlambat akibat terbatasnya kemampuan dalam bidang pendanan. Dengan terbatasnya sumber Pendapatan asli daerah (PAD) tidak banyak yang dapat dilakukan dalam emmberikan pelayanan maupun kemidahan bagi masyarakat (Yuningsih Nining, 2005)

\section{Metode Penelitian}

Berdasarkan jenis penelitianya, maka penelitian ini menggunakan metode kualitatif yang dilakukan dalam penelitian deskriptif pada penelitian studi kasus. Tipe dari penelitian ini berusaha untuk mendeskripsikan kemitraan Pengelolaan pariwisata dan Dampak dari Kemitraan Dalam Pengelolaan Objek Wisata Gunung Galungung antara Dinas Pariwisata, Pemuda dan Olahraga Kabupaten Tasikmalaya, PT. Perhutani dengan masyarakat. Teknik pengambilan data yang digunakan yaitu menggunakan teknik observasi, wawancara, serta dokumentasi. Dalam menganalisis data yang diperoleh, peneliti menggunakan analisis data yang bersifat induktif yaitu analisis yang berdasarkan data yang diperoleh. Mengacu pada pendapat Ghoni (1997) Penelitian kualitatif adalah jenis penelitian yang mengahasilkan penemuanpenemuan yang tidak dapat dicapai (diperoleh) dengan menggunakan prosedur-prosedur statistik atau dengan cara-cara lain dari kuantifikasi (pengukuran). penelitian kualitatif lebih berupaya untuk menciptakan teori baru dari pada menguji kebenaran sebuah teori. 


\section{Pembahasan}

\section{a. Pengelolaan Pariwisata}

Pariwisata merupakan sumber retribusi terhadap pendapatan daerah yang sangat potensial, hal tersebut terlihat hampir di setiap daerah mempunyai obyek pariwisata yang menjadi sorotan utama dalam meningkatkan pendapatan asli daerahnya atau menjadi ikon tersendiri dari daerah tersebut. Tidak sedikit daerah yang membentangkan lahannya menjadi lahan pariwisata dan menjadi sorotan publik wista alam. Salah satunya ada di Kabupaten Tasikmalaya dengan wisata Gunung Galunggung yang menyajikan pemandangan alam dan juga udara sejuk untuk setiap wisatawan yang berkunjung kesana. Gunung Galunggung merupakan Obyek wisata teratas yang banyak diminati oleh pengunjung dibandngkan dengan obyek wisata lainnya yang berada di Kabupaten Tasikmalaya. Gunung Galungung juga mampu mendatangkan bukan hanya wisatawan lokal tetapi wisatawan Internasioanal pun minat berkunjung.

Pembentukan struktur baru dalam tata kelola pariwisata gunung galunggung melalui kerja sama antara pihak KPH unit III Tasikmalaya yang merupakan suatu unit lembaga yang diberikan wewenang oleh perum Perhutani Jawa Barat untuk mengelola kawasan hutan lindung di gunung galunggung. KPH unit III ini menaungi LMDH dan Koparga. Namun Koparga dibawah naungan perhutani dengan kawasan hutan lindung dan kawasan yang dapat memberdayakan oleh masyarakat desa. Sedangkan koparga merupakan masyarakat desa yang aktif melakukan kegiatan ekonomi seperti pelaku unit usaha di sekitar kawasan wana wisata.

Pelaku usaha dibedakan menjadi dua pihak, yaitu pihak DISPARPORA yang diwakilkan oleh KOMPEPAR dengan daerah berjualan di daerah milik Pemda dan KOPARGA dibawah naungan PT. Perhutani dengan daerah berjualan di lahan milik KPH Perhutani. Pemerintah Kabupaten Tasikmalaya memberikan wewenang kepada DISPARPORA untuk mengelola kawasan wana wisata dengan terjalin kerja sama yang menetapkan kebijakan berupa masuk kawasan wana wisata satu pintu. Hasil yang diperoleh melalu ticketing merupakan share antara KPH PT.Perhutani dan DISPARPORA. 
Gambar 1 : Bentuk Kelembagaan tata kelola baru

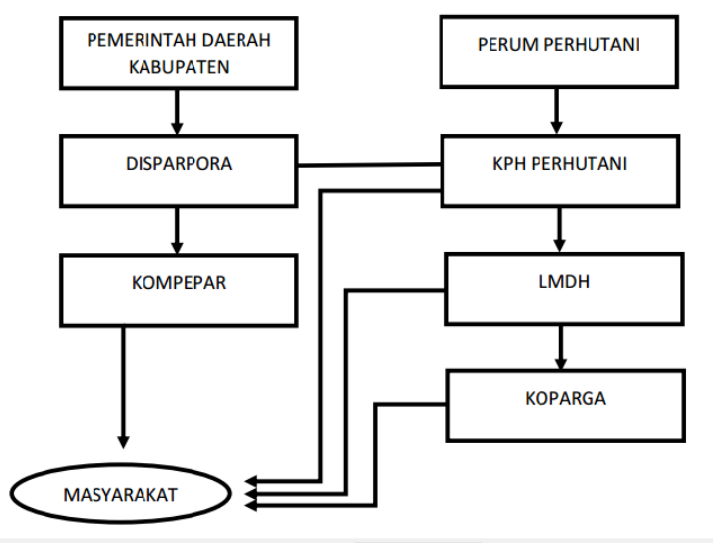

Sumber : Dinas Pariwisata, pemuda dan olahraga (2018)

Pengelolaan pariwisata yang dilaksanakan di wisata Gunung Galunggung terbagi menjadi dua bagian. Pengelola dari luas kawasan Gunung Galunggung keseluruhan yaitu $125.377 \mathrm{Ha}$, pengelola tersebut yaitu dari pihak Perhutani dan Dinas Pariwisata, Pemuda dan Olahraga yang menggandeng mitra kerja dalam pengelolaan pariwistanya yaitu KOMPEPAR (Kelompok Penggerak Pariwisata) dan KOPARGA (Koperasi Pariwisata Galunggung ) yang beranggotakan dari masyarakat sekitar wilayah Gunung Galunggung. Di bagian pertama Kawasan Wisata Galungung/kawah Gunung Galunggung yang di kelola oleh Perhutani yaitu Luas kawasan : 124,027 Ha (Kawasan Hutan lindung : 16,527 Ha, Kawasan Wisata 58,5 Ha, Kawah : $49 \mathrm{Ha}$ ).

Sedangkan pihak Dinas Pariwisata Pemuda dan Olahraga seluas 1,5 $\mathrm{Ha}$ yaitu Kawasan Bak Rendam Air Panas maka dari itu ada pembagian pungutan Retribusi antara Perhutani dan Dinas Pariwisata Pemuda dan Oalah raga yang diataur dalam Perda Kabupaten Tasikmalaya No.9 tahun 2011 dan SK Adm. Perhutani/ KPH Tasikmalaya No 33/kpts/TSM/III/2014 yaitu retribusi sebesar Rp 3000 untuk wilayah pengelolaan Perhutani dan untuk wialayah Pengelolaan Dinas pariwisata, Pemuda dan olahraga sebesar Rp 3000. Serta ada pungutan sebesar Rp 500 untuk jasa asuransi seperti yang terlampir gambar di bawah ini : 
Gambar 2 : Karcis Tanda Masuk Kawasan Wisata Gunung Galunggung

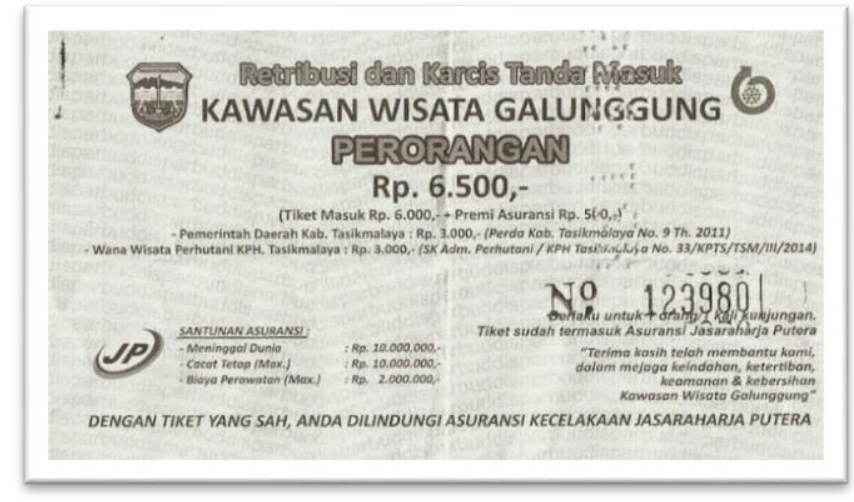

Sumber : Hasil Observasi di Obyek Wisata Gunung galunggung (2018)

Dengan adanya kerjasama dengan masyarakat memberikan dampak positf bagi pengelolaan pariwisata. Selain itu kerjasama yang dilakukan oleh pihak Dinas Pariwisata, pemuda dan Olahraga serta PT Perhutani Jabar Banten dengan masyarakat akan menjamin terjadinya peningkatan dalam pendapatan maka dari itu terjalinnya kemitraan antara Dinas Pariwisata, pemuda dan Olahraga serta Perhutani dengan masyarakat sebagai usaha untuk mewujudkan pengelolaan dan pelayanan terbaik terhadap pengunjung wisata serta mewujudkan peningkatan Pendapatan Asli Daerah di kabupaten Tasikmalaya dalam Bidang Pariwisata.

Berdasarkan hasil penelitian yang telah dilakukan, maka hasil yang didapat yaitu kegiatan pengelolaan pariwisata yang dilakukan di Obyek Wisata Gunung Galungung Kabupaten Tasikmalaya. Dalam hal ini di Obyek wisata Gunung Galunggung telah menerapkan kemitran atau kerjasama dalam pengelolaan pariwisatanya. Sesuai dengan teori kemitraan menurut Putra (2013) menyebutkan bahwa Kemitraan adalah suatu konsep kerjasama yang memiliki kriteria seperti dilakukan lebih dari satu pihak, mempunyai kebutuhan masing-masing, namun sepakat mencapai visi dan tujuan untuk meningkatkan kapasitas. Berkaitan dengan hal tersebut sudah sesuai dengan pengelolaan pariwisata yang terjadi di Obyek Wisata Gunung Galunggung Kabupaten Tasikmalaya dimana dalam pengelolaan pariwisatanya melakukan kerjasama atau kemitraan antara Dinas Pariwisata, pemuda dan Olahraga serta Perhutani dengan masyarakat yang mempunyai tujuan yaitu 
meningkatkan Pendapatan Asli Daerah seperti hasil wawancara dengan Bapak Toni staf bagian Seksi kerjasama dan kemitraan Dinas Pariwisata.

\section{b. Kemitraan Pengelolaan Pariwisata}

Terjalinnya kemitraan antara Dinas Pariwisata, pemuda dan Olahraga dengan masyarakat (kompepar) serta PT.perhutani dengan masyarakat (koparga) mengingat dengan adanya bentuk kontrak melaui M.O.U yang masing-masing mempunyainya kemudian ada tiga prinsip kunci yang perlu dipahami dalam membangun suatu kemitraan oleh masing-masing anggota kemitran yang diungkapkan Kuswidanti. Prinsip-prinsip ini penting di perhatikan dalam menjalin kemitraan antar pihak bermitra karena dalam menjalin kemitraan harus melihat karakteristik dari prinsip yang dijalankan bersama.

\section{Prinsip Kesetaraan (Equity)}

\section{a. Koordinasi Kemitraan}

Koordinasi yang dilakukan oleh pihak dinas terhadap pengelolaan pariwisata dilakukan setiap 1 tahun sekali. Hal tersebut dengan adanya sosialaisasi ini mengharapkan pihak mitra faham dengan tugas pelaksanaan program pengelolaan pariwisata yang dimana koordinasi ini dilakukan atas dasar pencapaian tujuan bersama yaitu pencapaian peningkatan Pendapat Asli Daerah. Sebagai mana Dinas Pariwisata, pemuda dan Olahraga mempunyai tugas pokok melaksanakan urusan Pemerintah Daerah terkait dengan Bidang Pariwisata, Pemuda dan Olahraga.

Dari tugas pokok di atas yang bertangung jawab dalam kasus ini adalah seksi kerjasama dan kemitraan yaitu melaksanakan penyiapan bahan perencanaan, pengaturan, pengembangan kerjasama dan kemitraan pariwisata.

Dari tugasm pokok diatas dinas pariwisata harus menjalani teknis atau alur pelaksanaan koordinasi terkait dengan kemitraan dan kerja sama antara pihak mitra. Dalam hal ini dinas pariwista mempunyai mitra kerja dalam pengelolaan pariwisatanya yaitu Kompepar. alur koordinasi yang dilakukan oleh pihak bermitra 
Gustian Riadi Saputra,dkk. Kemitraan Pengelolaan Pariwisata... | 321

yaitu dari bawah keatas bahwasanya koordinasi yang dilakukan pihak dians pariwisata dengan Msyrakat Kompepar itu koodinasi terkait dengan perkembangan pengelolaan pariwisata serta masukan atau hasil pantauan monitoring akan di koordinasikan melewati alur yang sudah di jelaskan di atas. Tidak hanya pihak Pemerintah yang melaksanakan koordinasi dalam lingkup pengelolaan pariwisata di Gunung Galungung Pihak PT.Perhutani juga memiliki tujuan dalam pencapaian pengelolaan terbaik khususnya di Objek Wisata Gunung Galunggung ini dimana tugas pokok dari PT. Perhutani tertulis dalam visi yaitu : Menjadi pengelola hutan lestari untuk sebesar-besarnya kemakmuran rakyat.

Adapun tugas dari Koparga dalam melaksanaka tugas pengelolaan nya kooparga memiliki kewajiaban sebagai berikut:

1. Melaksanakan kegiatan pengelolaan atas sarana yang tersedia di obyek wisata cipanas galunggung secara profesioanal.

2. Melaksanakan pencatatan atau pembukuan keuangan atas pendpatan atas kegiatan kerja sama serta catatan atau pembukuan keuangan atas setoran sharing dari setiap warung makan kepada pihak PT. Perhutani.

3. Melaksanaka pembagian uang bagi hasil sesuai porsi yang diatur, kepada pihak-pihak yang berhak menerimanya, khusus pelaksanaan pembayaran prosentase kepada pihak PT. Perhutani yang akan transparan kepada pihak Koparga dengan menunjukan laporan pembukuan keuangan yang di buat pihak mitra kerjadengan jadwal yang telah di sepakati.

4. Ikut berperan aktif dengan ijin dan sepengetahuan pihak PT. perhutani untuk menangani pengamanan, pencegahan kebakaranhutan, penertiban kawasan hutan, naik di lokasi yang menjadi obyek kerjasama maupun lokasi hutan sekitar.

5. Melaksanka rahan dan petunjuk teknis dari pihak PT. Perhutani dalam pelaksanaan kegiatan kerjasama. 
6. Secara aktif melibatkan dan memberikan pembinaan kepada masyarakat sekitar lokasi dalam kegiatan kerjasama sesuai kapasitasnya.

7. Meaga kebersihan dan merawat sarana dan prasarana di obyek wisata yang sudah rusak, sementara masih di perlukan oleh para pangunjung wisata.

8. Secara optimal berperan aktif dalam menjaga, mengamankan dan melestarikan sumber daya alam yang ada, termasuk keindahan, kenyamanan, dan kebersihan serta sarana prasarana yang ada.

Dari tugas diatas maka koordinasi yang dilaksanaka oleh pihak PT.Perhutani dengan masyarakat atau koparga itu di jalankan setiap seminggu sekali dimana koordinasi tersebut membicarakan hasil pendapatan sehari dan arus kunjungan wisatawan serta koordinasi permaslahan jika ada. pihak yang bermitra memiliki tugas dan fungsi untuk menjaga dan melestarikan lingkungan dengan asas manfaat bersama yang memiliki spirit pelayanan terbaik bagi masyarakat/wisawatn dan memiliki visi untuk memfasilitasi agar wisatawan merasa nyaman dan aman tidak hanya itu pihak PT. Perhitani koordinasi yang dilakukan yautu dengan pemberian masukan yang nantinya menjadi bahasan pada saat musyarawarah atau tahap pelaporan yang dilakukan oleh pihak mitra maupun pihak PT. Perhutani. Koordinasi ini nantinya akan dipantau atau di monitoring melalui proses tahapan akhir oleh masing-masing pihak.

\section{b. Sistem Monitoring}

Sesuai dengan temuan dalam penelitian ini bahwa Pemerintah Kabupaten yang diwakili oleh Dinas Pariwisata, Pemuda dan Olahraga selalu mengadakan pemantauan atau monitoring pada pengelolaan wisata Gunung Galungung. Pemantauan yang dilakukan adalah tim khusus dari utusan bagian dinas pariwisata, Pemuda dan Olahraga yang di lakukan dengan system 3 bulan sekali guna menangani daya tarik wisata terutama kawasan gunung galunggung bagian bak pemandian air panas galunggung yang di kelola oleh pihak pemerintah kabupaten atau Dinas Pariwisata, Pemuda dan Olahraga yang menggandeng Kompepar (kelompok penggerak pariwisata). Tidak hanya Pihak Pemerintah Kabupaten saja yang melakukan pemantaua tetapi dalam 
pengelolaan pariwisata di Gunung Galunggung ini Pihak Perhutani melaksanakan monitoring.

Pihak perhutani memiliki strategi khusus dalam system pengelolaan kedalam bentuk pelaporan untuk terciptanya pengelolan yang terstruktur dan tentunya memiliki tujuan yaitu meningkanya pendapatan serta meningkatnya daya Tarik wisatawan, dengan system per periode 1 tahun sekali yang telah di jelaskan dengan tahap ini memiliki pelaporan jangka panjang yang nantinya menjadi laporan kepada pihak Dinas atau pemerintah kabupaten yang di kalkulasikan menjadi pendapatan asli daerah khusus yang di kelola pihak PT. Perhutani dengan Koparga, untuk pelaporan per dua minggu yang sudah di jelaskan bahwa pelaporan tersebut akan melihat jangka menengah naik turunnya wisatawan serta per jam 16.00 akan menjadi tolak ukur perhutani bahwa pendapatan hasil perhari akan terlihat jelas kunjugan wisatawan di gunung galunggung khususnya lahan Kawah Gunung Galunggung.

\section{Prinsip Azaz Manfaat Bersama (mutual benefit)}

Pada prinsip manfaat bersama kemitraan yang sudah dijlankan dalam pengelolaan pariwsata di Gunung Galunggung, prinsip tersebut sudah menerapkan dalam kemitraannya. Dimana manfaaat tersebut akan berbedabeda bagi pihak mitra dalam pengelolaan pariwisata manfaat yang didapat sesuai dengan Adendum Perpanjangan Perjanjian Kerjasama Kemitraan antara Perusahaan Umum (Perum) Kehutanan Negara dengan Koperasi Pariwisata (Koparga) Nomor 009/PKS KBM-WJL.I/2017. Maupun Pemerintah Kabupaten dengan Kelompok Penggerak Pariwisata (Kompepar).

\section{a. Manfaat bagi Pemerintah Kabupaten dan pihak Mitra (Kompepar)}

Manfaat dari kemitraan ini akan berdampak positif bagi pemerintah kabupaten selain dari meningkatnya pendapatan asli daerah, masyarakat sekitar juga dapat di berdayakan sebagai pengelolaan pariwista dan akan menimbukan sejahteranya masyarakat sekitar. Manfaat tersebut juga dirasakan oleh pihak mitra bahwa penyerapan tenaga kerjalah yang memberikan 
dampak positif bagi warga di sekitaran objek wisata Gunung Galunggung, namun ada hal yang memberikan informasi terkait pembebasan lahan yang ingin di kelola langsung oleh pihak Kompepar. Hal ini seharusnya Dinas Parwisata lebih detail dalam perihal pemberian hak pengelolaan ataupun dalam pembuatan kebijakan dalam lingkup sosialaisi terhadap kelompok penggerak pariwisata selaku mitra kerja dari dinas pariwisata karena pengelolaan tersebut di limpahkan kepada pihak DISHUB dan membuat pihak mitra merasa tidak diberdayakan dalam pengelolaan lahan parkir.

Adapun pembagian hasil yang di laksanakan pada pihak mitra dengan Pemerintah Kabupaten Kemitraan antara Pemerintah Kabupaten dengan Kompepar ada sistem bagi hasil dalam pengelolaan nya yaitu 30\% untuk pihak mitra $70 \%$ untuk Pihak Pemerintah Kabupaten hal ini memberikan hal positif bagi masyarakat atau Kompepar karena dengan adanya keterlibatan pengelolan pariwisata dengan system bagi hasil ini merupakan perjanjian yang di sepakati bersama dan akan memberikan efek positif bagi pihak mitra.

\section{b. Manfaat Bagi PT. Perhutani dan Pihak Mitra (Koparga)}

Hal serupa dirasakan oleh pihak PT.Perhutani Jabar Banten terkait dengan manfaat kemitran yang dirasakan oleh pihak Perhutani dengan Koparga. pihak perhutani memberikan apresiasi terhadap kerjasama atau kemitraan yang dilakukannya dalam pengelolaan dengan adanya kemitraan yang sudah dilaksanakan dengan contoh sudah terorganisirnya system pengelolaan yang terkelola dengan baik. Adapun pendapat dari masyarakat pengelolaan pariwisata (KOPARGA) terkait dengan manfaat yang dirasakan oleh masyarakat yaitu penyerapan tenaga kerja terlebih masyarakat sekitar merasa terbantu karena diberikannya ijin usaha, diberi lahan sewaan dengan harga terjangkau.

Dapat kita ketahui pada Adendum Perpanjangan Perjanjian Kerjasama Kemitraan antara Perusahaan Umum (Perum) 
Gustian Riadi Saputra,dkk. Kemitraan Pengelolaan Pariwisata... | 325

Kehutanan Negara dengan Koperasi Pariwisata (Koparga) Nomor 009/PKS KBM-WJL.I/2017. Menyatakan bahwa perjanjian kemitraan tersebut ada pembagian hasil sesuai pada pasal 4 yaitu besaran hasil kerjasama : pengelolaan bak rendam, pengelolaan parkiran,pengelolaan lokasi perkemahan, pengelolaan fasilitaskesenian dan pengelolaan persewaan banrenang maka diatur dan di sepakati pembagian bahwa pengelolaan tersebut dalam system bagi hasil melalui perjanjian yaitu pihak mitra mempunyai hak pengelolaan besaran pendapatan yang akan di miliki adalah sebesar 30\% sedangkan pihak PT.Perhutani sebesar $70 \%$ dengan kesepakatan tersebut pengelolaan pariwisata di Gunung galunggung khususnya wilayah Kawah Gunung Galungung serta bak rendam air panas yang di bagi menjadi : pengelolaan bak rendam, pengelolaan parkiran,pengelolaan lokasi perkemahan, pengelolaan fasilitas kesenian dan pengelolaan persewaan ban renang.

\section{Prinsip keterbukaan ( transparansi)}

Prinsip ini melihat dengan cara pengelolaan kegiatan apakah pengelolaan kegiatan tersebut sudah berjalan sesuai aturan yang disepakati atau belum maka dapat terlihat dengan melaui transparansi kegiatan pengelolaan pariwisata dan hasil kegiatan pengelolaan. Sesuai hasil penelitian bahwa prinsip Keterbukaan sudah dijalankan oleh masing-masing pihak terutama dengan Pemerintah Kabupaten Tasikmalaya (Dinas Pariwisata, Pemuda dan Olahraga) dimana hal ini adalah prinsip yang sangat berpengaruh terhadap transparansi antara pihak pengelola.

\section{a. Transparansi Kegiatan Pengelolaan pariwisata}

Sesuai dengan temuan pada penelitian bahwa saling terbukanya antar pihak akan mengantarkan kepada hasil terbaik terhadap pengelolaan pariwisata di gunung galunggung dimana program yang sudah di susun demi lancranya pengelolaan pihak pemerintah sudah mengupayakan sedemikian rupa terkait keterbukan seluruh aktifitas pengelolan pariwisata dan yang 
dilakukan pihak dinas pariwisata yaitu terbukanya system ticketing yang tulis melalui tiket masuk atau karcis yang dikelola bersama yaitu pihak pemerintah Kabupaten maupun perhutani dengan masyarakat (kompepar dan koparga) tidak hanya itu pihak dinas terbuka dalam segala aktifitas lainnya yang menyangkut dengan pengelolaan pariwisata di Gunung Galunggung.

Sedangkan PT Perhutani terhadap keterbukaan mitra dengan pihak perhutani dengan adanya prinsip menjaga lingkungan dan memberikan pelayan terbaik, mengkoordinasi, membina dan mengawasi terhadap pengelolaan pariwisata dan hal tersebut sangat terbuka mengingat dalam hal ini good governance adalah prinsip dari PT. Perhutani dalam pencapaian kerjasama dan pelayanan terhadap wisatwan guna memberikan dampak terbaik bagi daya Tarik wisata yang berdampak secara khusus yaitu meningkatnya pendapatan asli daerah Kabupaten Tasikmalaya.

\section{b. Hasil Kegiatan Pengelolaan Pariwisata}

Dengan adanya pengelolaan pariwista terebut maka yang akan di selaraskan dengan aktifitas kegiatan pengelolaan adalah system pelaporan kerja terhadap pengelolaan pariwissata, dalam hal ini pihak PT Perhutani memeiliki tugas untuk system pelaporan terkait dengan pengelolaan pariwisata.keterbukaan terhadap pengelolan pariwista sangat lah penting seperti halnya yang dilakukan oleh pihak PT Perhutani yang nantinya menjadi tolak ukur pendapatan Asli Daerah dan itu di lakukan setiap setahun sekali tidak hanaya pelaporan dalam jangka panjang tetapi yang dilaksanaka pelaporan tersebut setiap bulan pun pihak PT. Perhutani memberikan laporan terkait pendapatan atau hasil dari kunjungan arus wisatwan yang mengunjungi wisata Gunung Galunggung Adapun pelaporan mitra kerja kepada pihak PT Perhutani untuk menganalisis wisatawan yang mengunjungi ke Gunung Galunggung. 
Pelaporan khusus untuk pelaporan wisatawan masuk, kendaraan masuk serta retrubusi yang didapatkan dalam jangka panjang, menengah maupun pendek. Sehingga PT Perhutani mengetahui perkembangan arus wisatawan masuk yang berkungjung ke Gunung Galunggung yang nantinya akan di laporkan secara formal kepada Pemerintah Kabupaten. Pelaporan tersebut sebagai simbol bahwa perkembangan setiap hari setiap minggu bahkan tahun akan berubah. Dalam hal keterbukaan tidak hanya system pelaporan saja antar pihak juga harus mengevaluasi atau mengidentifikasi permasalahan yang ada pada pengelolaan pariwisata di Obyek Wusata Gunung Galunggung. Adapun Terkait dengan keluhan dari Pemerintah dan PT. Perhutani maupun mitra pengelolan (masyarakat)

Permasalahan atau keluhan yang dirasaakan pihak pemerintah dalam hal ini adalah pembuat kebijakan sama sekali tidak ada permaslahan serius atau permasalahan khusus terlebih pengelolaan tersebut tidak semua di berikan kepada pihak mitra sama hal nya dengan pihak PT. Perhutani dengan pihak Koparga dalam penanganan permasalahan antar pengelolan sudah terjalin dengan baik dan tidak ada masalah apapun dalam pengelolaan nya dengan adanya SK yang mengatur bahwa pengelolaan tersebut sudah tertera aturan yang kuat dalam system tata kelola pengelolaan pariwisata dengan itu menyatakan bahwa setiap pengelola dari PT. Perhutani maupun Koparga sudah jelas dan terkelola dengan adanya SK dan M.O.U yang di sepakati oleh Pihak Perhutani dengan Pihak mitra yaitu Koparga.

Adapun keluhan dari pihak mitra kepada pihak Pemerintah Kabupaten dalam hal ini adalah DISPARPORA Kabupaten Tasikmalaya bahwa keluhan yang dirasakan oleh pihak mitra adalah perihal kepercayaan terhadap mtra dalam pengelolaan parkir sekitaran wisata yang di kelola oleh DISPARPORA yang menggandeng DISHUB Kabupaten Tasikmalaya untuk mengelola lahan parkir tersebut dan hal ini seharusnya pihak pemerintah memiliki upaya lain atau terobosan agar masyarakat sekitar bisa 
lebih diberdayakan dalam hal pembebasan lahan parkir tersebut mengingat keputusan dan pembuat kebijakan semua diserahkan kepada pihak pemerintah maka yang di permasalahkan disini adalah ketidak percayanya terhadap pengelolan lahan parkir.

Hasil penelitian menunjukan bahwa mengukur kemitraan dengan melalui prinsip keterbukaan dapat diambil garis besar bahwasannya pengelolaan dengan bermitranya atau keterlibatan pengelolaan dengan masyarakat sudah terlihat jelas terbuka dengan berbaghai aspek yang telah di paparkan diatas yaiu terkait Keterbukan Retribusi, Perjanjian Kontrak Kerja (M.O.U), Kegiatan Kepariwisataan, Tugas atau Fungsi Pengelola, Pelaporan, serta Keluhan atau Permasalahan yang di rasakan antar pihak.

Berdasarkan ketiga prinsip tersebut berjalan dengan baik terkait kemitraan pengelolaan pariwisata di objek wisata gunung galunggung kabupaten tasikmalaya ketiga prinsip tersebut yaitu prinsip kesetatraan, prinsip azas manfaat bersama (mutual benefit) dan prinsip keterbukaan ketiga prinsip tersebut sudah cukup membuktikan bahwa pada pengelolaan pariwisata di gunung galunggung telah mengajak pemerintah dan masyarakatnya untuk ikut berperan dan terlibat dalam proses kegiatan pariwisata yang berjalan dengan menerapkan kemitraan.

Dalam usaha meningkatkan Pendapatan Asli Daerah yang berasal dari sektor pariwisata, pemerintah Kabupaten Tasikmalaya melakukan upaya perubahan dan pengembagan sektor pariwisata. Dengan harapan sektor pariwisata akan menyumbang kontribusi yang lebih besar lagi nantinya untuk PAD.

Seperti penjelasan diatas yang telah memaparkan apa saja yang menjadi dasar untuk mendapatkan hasil yang baik dalam pengelolaan pariwisata dan apa saja yang menjadi keuunggulan dalam menata kemitran dan kerja sama pada pengelolaan pariwisata yang mempengaruhi Pendapatan Asli Daerah dari sektor pariwisata khususnya dari Obyek Wisata Gunung Galunggung. Adapun yang menjadi tolak ukur dalam Pendapatan Asli Daerah yaitu dengan Pendapatan Retribusi yang dihasilkan 
dari kunjungan wisatawan yang berkunjung ke Obyek Wisata Gunung Galunggung dengan hal tersebut maka faktor utama dari retribusi tersebut hasil pengelolaan yang baik menata dan memberikan pelayanan baik bagi wisatawan dengan melalui kemitraan merupakan terobosan untuk melakukan pelaksanaan pengelolaan yang terstruktur dan terkelolanya pariwisata yang aman, nyaman serta menmbahnya Daya Tarik Wisata yang dapat mempengaruhi penambahan kunjungan wisata yang tentunya akan berdampak terhadap Pendapatan Asli Daerah pada sektor wisata khususnya di Obyek Wisata Gunung Galunggung.

\section{c. Peningkatan Pendapatan Asli Daerah}

Adapun data hasil dari pengelolaan pariwisata peningkatan Pendapatan Asli Daerah melalui retrubusi yang masuk ke wisata Gunung Galunggung yang menjadi tolak ukur dari retribusi tersebut adalah Arus Kunjungan wisata dan Realisasi Target Pendapatan.

\section{Retribusi Daerah}

Obyek wisata Gunung Galunggung merupakan obyek wisata yang menjadi sorotan publik pertama dalam kunjungan di Kabupaten Tasikmalaya dibandingkan obyek wisata yang lain dengan itu maka retribusi yang masuk akan mempengaruhi terhadap pendapatan asli daerah kabupaten tasikmalaya dalam sektor pariwisata.

\section{a. Arus Kunjungan Wisata}

Retribusi daerah ini dapat kita lihat melalui jumlah pengunjung yang datang ke Obyek Wisata Gunung Galunggung dan realisasi target PAD. Berikut tabel data arus kunjungan wisatawan yang berkunjung ke beberapa destinasi wisata di Kabupaten Tasikmlaya berikut Grafik 1 
Grafik 1 : Data Kunjungan Arus Wisatawan Yang Berkunjung Ke Beberapa Destinasi Wisata Di Kabupaten Tasikmalaya $2015-2017$

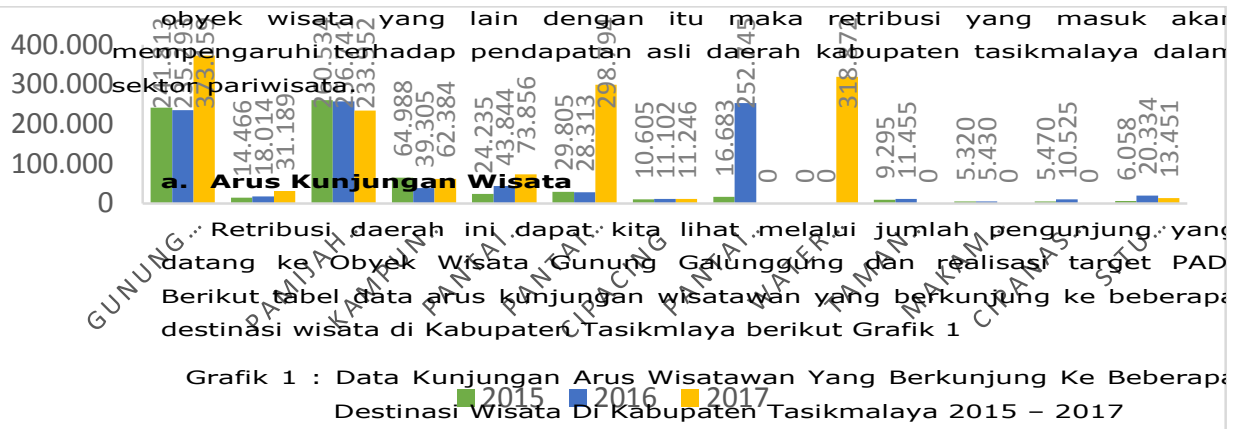

G. Retribusi daerah ini dapąt. kitą lihat melalui jumlah pengunjung. yan!

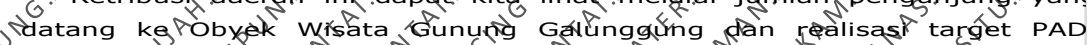
Berikut tabel afata arus kumjungan visata kân yaring befkunjung ke beberap: destinasi wisata di Kabupater Tasikmlaya berikut Grafik 1 C

Grafik 1 : Data Kunjungan Arus Wisatawan Yang Berkunjung Ke Beberap Destinasi Visata Díkabupateñ Tasikmalaya 2015 - 2017

Sumber : Disparpora Kabupaten Tasikmalaya (2018)

Dapat kita lihat dari data yang telah diperoleh dari Dinas Pariwisata, Pemuda dan Olahraga Kabupaten Tasikmalaya, bahwa terjadi Penurunan kunjungan wisatawan ke Wana Wisata Gunung Galunggung dari tahun 2015 sampai 2016 sebanyak 6,52 persen dengan penurunan pertumbuhan kunjungan menurun sebesar 0,42 persen, Namun terjadi kenaikan kunjungan wisatawan dari tahun 2016 menuju tahun 2017 sebanyak 137,866 dengan peningkatan pertumbuhan kunjungan sebesar 37.02 persen.

Dengan adanya penurunan pada tahun 2015-2016 tentunya pemerintah kabupaten yang di wakilkan oleh Dinas Pariwisata harus gencar menganalisis sebab dari hal tersebut dan hal itu diseabkan oleh daya Tarik wisata serta faktor yang mendukung yaitu sarana prasarana. dapat kita ketahui bahwa fasilitas umum untuk kepentingan wisatawan sangat di perlukan.

Pemerintah kabupaten dalam hal ini adalah dinas pariwisata gencar memberikan pelayanan terbaik dengan membuat rencana pembangunan fasilitas dalam menunjang kepuasan wisatwan hal tersebut bisa kita lihat dengan wisata alam di kota dan kabupaten di Indonesia yang semakin majunya zaman dan semakin banyak pembaharuan atau inovasi serta fasilitas yang di sediakan oleh pihak pemerintah atau UPT pengelola pariwisata dengan adanya hal tersebut maka pemerintah berupaya untuk membenahi 
Gustian Riadi Saputra,dkk. Kemitraan Pengelolaan Pariwisata... | 331

pengembagan sektor wisata dengan melalui pembenahan pengelolaan pariwisata serta fasilitas yang diperlukan wisatawan

Dengan hal diatas maka tidak di pungkiri bahwa pengelolaan pariwisata merupakan hal utama dalam upaya menarik wisatawan agar merasa nyaman dan aman ketika berkunjung yang tentunya akan berdampak terhadap peningkatan pendapatkan asli derah yang sudah dipaparkan diatas bahwa dalam hal ini pihak Pemerintah Kabupaten dan perhutani menggandeng masyarakat untuk membantu mengelola ruang lingkup kemitraan yaitu bermitra dengan kompepar dan koparga agar pengelolaan tersebut bisa berkembang dan memberikan dampak baik bagi peningkatan dalam penataan pengelolaan, menamabh dan terkelolanya daya Tarik yang berinovasi, pengembangan fasilitas yang berpengaruh dalam minatnya pengunjung wisata yang akan berdampak terhadap pendapatan yang akan dihasilkan dari system pengelolaan tersebut.

\section{b. Realisasi target Pendapatan Asli Daerah}

Dari pengelolaan tersebut yang di laksanakan oleh dinas pariwisata maupun perhutani dengan masyarakat akan terlihat dengan adanya data arus kunjungan di obyek wisata gunung galunggung pendapatan yang dihasilkan dalam sektor pariwisata juga sangat memberikan bukti bahwa system pengelolaan yang di laksanakan di obyek wisata gunung galunggung tersebut bisa terlihat melalui pendapatan atau hasil dari pendapatan retribusi obyek wisata tersebut yaitu retribusi yang di pungut atas pengelolan pariwisata. Adapun realaisasi pendapatan sektor pariwisata di Obyek wisata Gunung Galungung Kabupaten Tasikmalaya berikut tabel dibawah ini. 
332 | Gustian Riadi Saputra,dkk. Kemitraan Pengelolaan Pariwisata...

Tabel 3 : Data Realisasi Pendapatan Asli Daerah Obyek Wisata Gunung Galunggung Kabupaten Tasikmalaya Tahun 2015-2017

\begin{tabular}{|c|c|c|c|c|c|}
\hline No & $\begin{array}{c}\text { Wana } \\
\text { Wisata }\end{array}$ & $\begin{array}{c}\text { Target } \\
\text { dan realisasi }\end{array}$ & $\begin{array}{l}2015 \\
(\mathrm{Rp})\end{array}$ & $\begin{array}{l}2016 \\
(\mathrm{Rp})\end{array}$ & $\begin{array}{l}2017 \\
(\mathrm{Rp})\end{array}$ \\
\hline \multirow[b]{2}{*}{1} & \multirow{2}{*}{$\begin{array}{c}\text { Kawasan } \\
\text { Wisata } \\
\text { Galunggung }\end{array}$} & Target & 468.000 .000 & 468.000 .000 & 575.000 .000 \\
\hline & & Realisasi & 642.142 .000 & 557.501 .000 & 616.754 .000 \\
\hline \multirow[b]{2}{*}{2} & Bak & Target & 35.000 .000 & 35.000 .000 & 55.000 .000 \\
\hline & $\begin{array}{l}\text { Rendam Air } \\
\text { Panas } \\
\text { Galunggung }\end{array}$ & Realisasi & 58.783 .000 & 61.254 .000 & 73.763 .000 \\
\hline
\end{tabular}

Sumber : Dinas Pariwisata, Pemuda dan Olahraga Kabupaten Tasikmalaya (2018)

Obyek wisata gunung galunggung merupakan obyek wisata yang memiliki retribusi dalam bidang tempat rekreasi dan olahraga terbesar di Kabupaten Tasikmalaya disbanding dengan obyek wisata kedua teratas yaitu pamijahan (wisata religi) gunung galunggung tercatat pada tahun 2017 per desember mencapai angka Rp 616.754.000 pemasukan pada pendapatan PAD. Dengan jumlah pengunjung 373,159 pengunjung yang datang di Obyek wisata Gunung Galunggung yang di bantu oleh pendapatan retribusi dari pemandian air panas galunggung yang di kelola oleh pemerintah kabupaten per desember tercatat pada tahun 2017 mengalami peningkatan yang signifikan mencapai angka Rp 73.763.000 dari target Rp 55.000.000 hal ini yang di sebebkan daya Tarik wisata gunung galunggung memiliki ciri khas yang menonjol selain dari kawah gunung galunggung yaitu air pans alami.

Dengan pengelolaan yang semakin ketat dan teratur dengan banyaknya upaya program kegiatan pengelolan yang dijalankan dan akan mempengaruhi terhadap minatnya pengunjung. Terjalinnya kerjasama pengelolaan ruang lingkup kemitraan 
Gustian Riadi Saputra,dkk. Kemitraan Pengelolaan Pariwisata... | 333

antara Pemerintah Kabupaten, Perhutani dengan Masyarakat juga memberikan dampak besar terhadap pelaksanaan kegiatan pengelolaan kepariwistaan di obyek wisata gunung galunggung.

Dapat terlihat dari pemaparan diatas bahwa kemitraan pengelolaan pariwisata antara Pemerintah Kabupaten, Perhutani dengan Masyarakat di Obyek Wisata Gunung Galunggung merupakan terobosa yang memberikan pengarih besar terhadap hasil Pendapatan Asli Daerah. Terlihat pada realisasi pendapatan tahun 2017 mengalami peningkatan yang sangat signifikan terlebih dalam system pengelolaan nya yang baik UPT wisata Gunung Galunggung selalu ber upaya untuk menjadikan Wisata Gunung Galungung adalah obyek wisata yang di kenal masyarakat luas dengan berbagai even atau kegiatan memberikan dayat tarik bagi wisatawan serta dengan memberikan fasilitas yang terbaik dan juga memberikan kenyamanan bagi wisatawan yang berkunjung ke Gunung Galunggung yang nantinya akan berpengaruh terhadap pendapatan asli daerah melaui retribusi/ pungutan pemasukan terhadap Wisata Gunung Galunggung.

\section{Kesimpulan}

\section{a. Pengelolaan Pariwisata}

Berdasarkan hasil penelitian dapat disimpulkan bahwa kemitraan pengelolaan pariwisata di Gunung Galunggung merupakan terobosan untuk menangani atau membantu dalam pengelolaan pariwisata yang menjadikan kekuatan dalam upaya meningkatkan pendapatan pada sektor pariwisata yang dilaksanakan oleh Pemerintah Kabupaten dan PT.Perhutani. Dalam hal pengelolaan Obyek Wisata Gunung ini memiliki 2 pengelola yang mempunyai kewajiaban untuk merawat dan melestarikan Obyek wisata tersebut dimana hasil penelitian menyebutkan bahwa ada Pembentukan struktur baru dalam tata kelola yang di laksanakan di obyek wisata Gunung Galunggung. Pelaku usaha dibedakan menjadi dua pihak, yaitu pihak DISPARPORA yang diwakilkan oleh KOMPEPAR dengan daerah meneglola di daerah milik Pemda dan KOPARGA dibawah naungan PT. Perhutani dengan daerah pengelolaan di lahan milik PT Perhutani. 


\section{b. Kemitraan Pengelolaan Pariwisata}

Aspek penting dalam menjalani kemitraan memiliki prinsip atau kunci dalam kemitraan yaitu ada prinsip kesetaraan, prinsip manfaat bersama (mutual benfit) dan prinsip keterbukaan yang akan berdampak dalam meningkatnya Pendapatan Asli Daerah yang meliputi dari Retribusi dengan melalui arus kunjungan dan realisasi target pendapatan.

\section{Prinsip kesetaraan (Equity)}

Kemitraan antara masing masing pihak baik pihak pemerintah, PT Perhutani dan masyarakat yang bermitra sudah sama-sama sejajar kedudukannya dalam mencapai tujuan yang disepakati bersama dimana kemitraan ini sudah memiliki struktur dalam organisasi kemitraan tersebut terlihat ketika alur koordoinasi yang sudah dibangun oleh masing masing pihak.

\section{Prinsip Azas Manfaat Bersama (mutual benefit)}

Manfaat yang didapatkan oleh DISPARPORA yaitu adanya penyerapan tenaga kerja, dapat membantu mengurangi angka kemiskinan dan pengangguran di desa serta membantu masyarakat guna meingkatkan kesejahteraan. Manfaat yang didapat oleh pihak PT. Perhutani yaitu perihal bermitra dengan Koparga merasa terbantu dalam pengelolaan khususnya mengelola kebersihan dan keamanan lingkungan wisata gunung galunggung di wilayah KPH perhutani. Manfaat bagi Kompepar maupun Koparga yaitu terbantunya dalam taraf hidup dalam pemberdayaan masyarakat atau perlibatan pengelolaan pariwisata sehingga pihak mitra mendapat pekerjaan dan otomatis mendapatkan tambahan pemasukan dengan system kepercayaan melalui kontrak kerja dan M.O.U yang disepakati bersama adapun manfaat yang dirasakan dalam pembagian hasil pengelolaan Pariwisata yaitu pihak Pemerintah Kabupaten dan PT.Perhutani memiliki kesepakatan bagi hasil yaitu $70 \%$ dan Mayarakat (Kompepar dan Koparga) sebesar $30 \%$. 


\section{Prinsip Keterbukaan (transparansi)}

Dalam prinsip ini, kegiatan kemitran sudah berjalan cukup terbuka terkait dengan informasi mengenai kegiatan pengelolaan pariwisata hal tersebut dirasakan oleh pihak PT. Perhutani dengan KOPARGA yang menilai kemkitraan ini sudah berjalan secara transparan. Namun berbeda dengan DISPARPORA yang bermitra denggan KOMPEPAR, meskipun secara keseluruhan dinilai cukup dalam mengelola pariwisata namun ada keluhan terkait dengan kepercayaan mengelola lahan parkir bahwa pihak mitra menilai kepercayan itu akan berdampak terhadap keterbukaan dan hal ini masih dirasa kurang dalam system pengelolaan yang di berikan oleh DISPARPORA beberapa kegiatannya terlebih mengenai kerjasama bersama pihak lain yaitu DISHUB untuk mengelola parkir sekitaran area lahan yang dikelola Pemerintah Kabupaten.

Berdasarkan hasil analis tersebut, maka dapat disimpulkan kemitraan berjalan sesuai prinsip yang menunjang suksesnya dalam bermitra, karena dengan ketiga prinsip ini menunjukan hasil yang cukup baik dalam membangun kemitraan terlebih kemitraan ini akan berdampak terhadap system pengelolaan yang dilaksanakan di obyek wista Gunung galunggung guna upaya meningkatkan Pendapatan Asli Daerah dalam sektor wisata dan pembangunan pariwisata di Gunung Galunggung Kabupaten Tasikmalaya terlebih pada prinsip kesetaraan dan prinsip azas manfaat bersama yang memberikan hasil yang signifikan bahwa kemitraan di jalan kan dengna baik namun terlihat hasil dalam pelaksaaan prinsip keterbukaan ada hal yang memberika data terkait dengan keprcayaan terhadap pengelolaan hal ini akan terlaksana ketika dinas pariwisata membuat kebijakan atau sosialaisasi dengan baik anatra pihak mitra dengan pihak Pemerintah Kabupaten.

\section{c. Peningkatan Pendapatan Asli Daerah}

Terkait dengan Pendapatan Asli Daerah dapat disimpulkan bahwa sektor pariwisata di Obyek wisata Gunung galungung sudah cukup baik 
telihat pada peningkatan jumlah retribusi yang diberikan Obyek Wisata Gunung Galunggung tiap tahunnya. Meskipun mengalami penurunan sedikit namun hal tersebut pihak pemerintah sudah memberikan strategi untuk menangani terkait Pendapatan Asli Daerah terutama dalam sektor pariwisata khususnya di Obyek wisata Gunung Galunggung.

Data realisasi pendapatan asli daerah setiap tahun mengalami peningkatan khusus pada 3 tahun terakhir ini antara target dengan realisasi sudah melampaui dari jumlah target hal tersebut Gunung Galunggung tercatat pada tahun 2017 per desember mencapai angka Rp 616.754.000 pemasukan pada PAD sektor pariwisata. Dengan jumlah pengunjung 373,159 pengunjung, hasil pendapatan wilayah Bak Rendam Air Panas Galunggung yang di kelola oleh pihak Dinas Pariwisata, Pemuda dan Olahraga Kabupaten Tasikmalaya pada tahun 2017 tercatat per desember mencapai angka Rp 73.763.000 pemasukan pada PAD Kabupaten Tasikmalaya sektor Pariwisata dengan target pemasukan yaitu Rp 55.000.000.

Maka dapat diambil garis besar dengan hasil pendapatan tersebut tidak dipungkiri bahwa yang berpengaruh terhadap angka capaian pendapatan adalah dari sistem pengelolaan pariwisata dalam hal ini dapat terlihat dalam system pengelolaan pariwisata yang dilaksanakan di Obyek Wisata Gunung galunggung terdapat kemitran untuk mencapai targret pendpatannya. Dari hasil penelitian memberikan hasil yang signifikan terhadap tatakelola serta sistem kegiatan kemitraan yang dilakukan guna mendapatkan hasil yang baik bagi Pendapatan Asli Daerah Kabupaten Tasikmlaaya hal tersebut terlaksana dan terlihat jelas dengan hasil yang didapat berbagai aspek yang dilaksanakan menjabarkan bahwa kemitraan ini harus di kembangkan dan dilaksanakan sesuai dengan kebijakan yang di sepakati bersama. 


\section{Saran}

1. Pihak Pemerintah Kabupaten (Dinas Pariwisata, Pemuda dan Olahraga dan UPT wisata Gunung Galungung).

Diharapkan pihak DISPARPORA untuk seentiasa merumuskan kebijakan-kebijakan mengenai pembangunan pariwisata yang ada di Kabupaten Tasikmalaya khusus nya di gunung galunggung Terkait dengan kejelasan program yang dilaksanakan seharusnya pihak pemerintah lebih memperhatikan program yang akan dilaksanakan terlebih program pelaksanaan pengelolaan pariwisata yang dilaksanaka pihak mitra supaya pihak mitra akan lebih giat dalam membantu kinerja pengelolaan pariwista dan saling terbuka antara pihak itu harus di utamakan karena dengan keterbukaan ini lah yang akan menimbulkan kemitraan yang akan berdampak terhadap pelayanan yang dilakukan oleh pihak mitra.

Saling percaya juga masih kurang terhadap mitra seharusnya pihak pemerintah memililki inisiatif atau pembuatan kebiijakan terkait pengelolan dan pemberdayaan masyarakat sekitar Gunung Galunggung terlebih dalam pengelolaan lahan parkir yang memberikan tugas nya kepada DISHUB. Dengan berbagai masukan terhadap pengelolaan bagian lahan Pemerintah kabupaten bahwa pihak pemerintah tidak bertindak tegas dan kurang memperhatikan pihak mitra dan bisa dikatakan kurang maksimal dalam pengelolaan lahan parkir karena kurang nya perhatian dan pemberdayaan pada pihak mitra .

Dengan semakin berkembangnya sektor pariwisata di kabupaten tasikmlaya maka retribusi yang akan masuk kedalam pendapatan asli daerah juga diharapkan meningkat. Adapun yang haris dikembangkan yaitu dalam system konsep 3A wisata yang menjadi tugas pemerintah agar masyarakat lebih gencar lagi memperhatikan pariwisata dengn konsep 3A yang di jadikan tolak ukur tersebut yaitu Attraction atau atraksi berupa keindahan dan keunikan alam budaya, peninggalan budaya bangunan bersejarah, lalu ada konsep accessibility atau aksesibilitas adalah sarana dan infrasturktur untuk menuju destinasi seperti jalan raya, ketersediaan sarana transportasi, dan rambu-rambu petunjuk sedang kan amenitas berkaitan dengna segala fisilitas pendukung seperti ketersediaan sarana untuk menginap, restoran atau 
warung dan segala fasilitas pendukung yang bias memenuhi kebutuhan dan keinginan wisatawan selama berada di destinasi.

Dengan adanya konsep 3A yang merupakan konsep pemerintah untuk menjadikan dayat Tarik wisata yang memberikan dampak terbaik bagi pengunjung wisata. Tidak hanya itu program pemerintah yaitu wonderful Indonesia merupakan produk pemerintah untuk memasarkan pariwisatanya dimata dunia, pemerintah kabupaten tasikmlaya seharusnya dapat memfasilitasi agar Gunung Galunggung dapat masuk ke dalam program tersebut, sehingga informasi dapat di akses ke seluruh dunia bagi calon pengunjung yang akan berkunjung ke wisata yang ada di Indonesia.

\section{DAFTAR PUSTAKA}

\section{Buku-buku}

Nanang Martono,(2011),"Metode Penelitian Kualitatif" Jakarta, RajawaliPress.

Sugiono, (2015), "Metode Penelitian Kuantitatif, Kualitatif dan R\&D" Bandung, Alfabeta.

Suttrisno Hadi, (1986) metode Research,Jakarta, Andi Offset.

Ghoni H.M Djunaidi,(1997)"Dasar-dasar penelitian kualitatif prosedur,teknik dan teori grounded" Surabaya

\section{Jurnal}

Abdul, S. W. (2015). Peran Dinas Pemuda, Olahraga, Kebudayaan Dan Pariwisata Dalam Mengembangkan Potensi Wisata Pantai Manggar Kota Balikpapan. IImu Pemerintahan, 3, 10. Retrieved from ejournal.ip.fisipunmul.ac.id

AMIM, A. (2017). Strategi pengembangan kawasan strategis pariwisata daerah banten lama kota serang.

Beatrix, M. (2017). Pola kemitraan pemerintah daerah, swasta, dan masyarakat dalam perwujudan mamasa sebagai destinasi pariwisata di sulawesi barat.

Cavaye, J. M. (2004). Governance and Community Engagement - The 
Australian Experience. Participatory Governance: Planning, Conflict Mediation and Public Decision Making in Civil Society, 85-102.

Fandi, K. (2012). Kemitraan Pengelolaan Sektor Pariwisata. Jurnal Administrasi Publik (JAP), 1(1), 47-55.

Farrah. (2017). Pola pengembangan wisata alam di kabupaten bogor. Jurnal Hospitality Dan Pariwisata, 3(1), 285-293.

Halsall, J. P. (2012). Community Governance: Where did it all go Wrong? Joaag, 10(10), 1-8.

Halsall, J. P., Oberoi, R., Cook, I. G., \& Wankhade, P. (2013). Understanding Community Governance: a Global Perspective. International Journal of Asian Social Science, 3(5), 1112-1127. https://doi.org/11.1039/b000000x

Irfan, M. (2015). Digital Repository Universitas Jember. KEMITRAAN PENGELOLAAN EKOWISATA MANGROVE BLOK BEDUL, 63. https://doi.org/10.1242/jcs.150862

Kanuna, R. S. (2014). Peranan Pemerintah Daerah dalam Pengelolaan Potensi Pariwisata di Kabupaten Toraja Utara. https://doi.org/10.1016/S00201693(00)81223-2

Muhammad, F. (2015). Bentuk Pengelolaan Potensi Pariwisatapantai Pangandaran Jawa Barat.

Mukhsi, D. (2015). Strategi Pengembangan Kawasan Pariwisata Gunung Galunggung ( Studi Kasus Kecamatan Sukaratu Kabupaten Tasikmalaya ). Jurnal Perencanaa Wilayah Dan Kota, 12(1), 1-11.

Mulyanie, E. (2016). Partisipasi masyarakat dalam pelestarian kawasan konservasi hutan di gunung galunggung kabupaten tasikmalaya. Geografi, 4(1), 1-14.

Nugroho, S. S. (2014). Pola Kemitraan Dalam Pengelolaan Pariwisata Di Kepulauan Karimunjawa Kabupaten Jepara.

Nurfadilah, K. A. (2017). Strategi Pengembangan Pariwisata Pantai Pangandaran (Studi Kasus di Kabupaten Pangandaran).

Petang, K., Badung, K., Kadek, N., Pebriani, D., Erviantono, T., Wiwin, K., \& Wismayanti, D. (2010). Kemitraan Pengembangan Sektor Pariwisata ( Studi Kasus: Bali Elephant Camp, Desa Wisata Carangsari.

Putra, A. S. (2013). POLA KEMITRAAN PARIWISATA DALAM MANAJEMEN ATRAKSI DESA WISATA PAMPANG KOTA SAMARINDA. Nasional Pariwisata, 5, 189-200.

SAPUTRO, A. S. (2016). Evaluasi Pengembangan Obyek Wisata Di Kabupaten Banyumas Dalam Meningkatkan Pendapatan Asli Daerah Tahun , 2014. 
340 | Gustian Riadi Saputra,dkk. Kemitraan Pengelolaan Pariwisata...

Totikidis. (2005). The Concept of Community Governance: A Preliminary Review Totikidis V 1 , Armstrong A F \& Francis R D. Corporate Governance.

Yuningsih, N. (2005). Peningkatan Pendapatan Asli Daerah ( Pad ) Melalui Pengembangan Potensi Obyek Wisata.

\section{Data Internet}

Republika.co.id.(2015). Tasikmalaya Siapkan Tiga Objek Wisata Ini Mendunia. Diakses dari :

https://www.republika.co.id/berita/nasional/daerah/17/09/18/gayahidu p/travelling/15/12/30/o05aak280-tasikmalaya-siapkan-tiga-objekwisata-ini-mendunia

koran-sindo.com.(2016). Potensi Wisata Tasikmalaya Luar Biasa. Di akses dari

http://koran-sindo.com/page/news/2016-07

10/4/23/Potensi_Wisata_Tasikmalaya_Luar_Biasa

validnews.co.id (2018). Retribusi di gunung galunggung ditertibkan.diakses dari :

https://www.validnews.id/Retribusi-Di-Gunung-Galunggung-

Ditertibkan-THY

Tasikmalayakab.bps.go.id.(2017). Kependudukan »Luas Daerah, Jumlah Penduduk dan Rata-Rata Kepadatan Penduduk. diakses dari :

https://tasikmalayakab.bps.go.id/statictable/2017/05/04/4/luas-

daerah-jumlah-penduduk-dan-rata-rata-kepadatan-penduduk.html

Jabarprov.go.id. (2017). Selayang pandang. Diakses dari :

http://jabarprov.go.id/index.php/pages/id/1046

Kknm.unpad.ac.id. (2018). DESA LINGGAMULYA. Diakses dari :

https://kknm.unpad.ac.id/linggamulya/desa-linggamulya-2/kondisidemografis/

\section{Peraturan Perundang-undangan}

Keputusan Menteri Pertanian : Kep- No. 944/kpts/OT.210/10/1997 Tentang Pedoman Penetapan Hubungan Kemitraan Usaha Pertanian.

Peraturan daerah Kota Tasikmalaya No. 8 Tahun 2014 Tentang Penyelenggaraan Kepariwisataan.

Undang-Undang No. 10 Tahun 2009 Tentang Kepariwistaan.

Undang-Undang No. 23 Tahun 2014 Tentang Pemerintah daerah. 
Gustian Riadi Saputra,dkk. Kemitraan Pengelolaan Pariwisata... | 341

Undang Undang No. 33 tahun 2004 Tentang Perimbangan Keuangan antara Pemerintah Pusat Dan pemerintahan Daerah.

Undang-Undang No. 32 Tahun 2014 Tentang Pemerintah daerah.

Undang-Undang No. 34 Tahun 2000 Tentang Perubahan Atas Undang-Undang Republik Indonesia Nomor 18 Tahun 1997 Tentang Pajak Daerah Dan Retribusi Daerah. 